\title{
A COMPARISON OF TWO RESPIRATORY SYMPTOMS QUESTIONNAIRES
}

\author{
BY \\ W. W. HOLLAND*, J. R. ASHFORD††, J. R. T. COLLEY*, \\ D. CROOKE MORGAN†, AND N. J. PEARSON† \\ From the Department of Clinical Epidemiology and Social Medicine St. Thomas's Hospital Medical School*, the \\ National Coal Board, Pneumoconiosis Field Research $\dagger$, and the Department of Mathematics, University of Exetert
}

\author{
PART I \\ METHODOLOGY AND OBSERVER VARIATION
}

It is generally recognized that, in epidemiological studies, the diagnosis of chronic bronchitis, and particularly of the early stages of the condition, is an uncertain process which depends essentially upon symptomatic inquiry of the subject. In such studies it is important that the techniques of inquiry should be standardized (Cochrane, Chapman, and Oldham, 1951) so that the results obtained by different investigators in different populations may be compared. Considerations of this kind have led to the evolution of questionnaires completed at one interview of each subject, which comprise a series of standard questions about particular respiratory symptoms (Fletcher, Elmes, Fairbairn, and Wood, 1959; Fairbairn, Wood, and Fletcher, 1959; Olsen and Gilson, 1960; Higgins, 1961 ; College of General Practitioners, 1961). In the United Kingdom the Medical Research Council (M.R.C.) Committee on the Aetiology of Chronic Bronchitis produced in 1960 a "Respiratory Symptoms Questionnaire" (Medical Research Council, 1960, 1961) which has since been applied in its original or in a modified form in a wide variety of epidemiological studies in many parts of the world.

As part of the National Coal Board's Pneumoconiosis Field Research (P.F.R.) (Fay, 1957; Fay and Rae, 1959) a short questionnaire about respiratory symptoms has, since 1958, been included in the standard medical examination (Rogan, Ashford, Chapman, Duffield, Fay, and Rae, 1961). To date the PFR Questionnaire has been asked of some 30,000 working coalminers, comprising about 95 per cent of the labour force employed at the $25 \overrightarrow{\vec{\theta}}$ collieries at which this research is undertakes. $\mathscr{\circ}$ Follow-up studies of respiratory symptoms we started in 1962, the second examination of eaci. individual taking place about 5 years after the first. As the selected collieries are situated throughout the main British coalfields, the answers given to the PFR Questionnaire are potentially useful for comparing the prevalence of respiratory symptoms amongst coalminers with that amongst other sections of the population. The majority of recent studies in other sections of the population have, however, been based upon the use of the MRC Questionnaire or its derivatives.

As there are appreciable differences between the form of the two questionnaires and the way in which they are applied, it was decided to carry out a field trial on a population of working coalminers in an attempt to establish a basis of comparison.

\section{THE Two QuestionnaIRES}

The shorter of the two versions of the MRC Respiratory Symptoms Questionnaire has been more widely used and was chosen as being more suitable to the conditions of the trial. It was employed in the standard form (Medical Research Council, 1961) apart from minor modifications to the questions $O$ about smoking habits which are listed in Appendix I. These consisted of asking the subject whether he $\stackrel{\oplus}{?}$ inhaled and asking specifically how much he was smoking of each type of tobacco product now. In the MRC version, the method of asking for smoking 
habits is left open to each interviewer. These questions dealing with smoking habits were the last to be asked of the subject and the changes which were introduced could not therefore have affected the answers to the earlier questions dealing with respiratory symptoms. The content of the questionnaire and the method of application have been described elsewhere (Holland, 1963).

The questionnaire used by the Pneumoconiosis Field Research is shown in Appendix II. It is similar in form and more concise than the MRC Questionnaire, making no reference to nasal catarrh, asthma, or hay fever, and no distinction between summer and winter cough and phlegm. In other respects the symptoms covered by the two questionnaires are the same, although the wording of the questions and the order in which they are put are not identical.

The PFR Questionnaire is applied by persons without medical qualifications. In the interests of standardization precisely the same wording is followed on each occasion and the use of additional probing questions is deliberately proscribed.

Because of the greater simplicity of the PFR Questionnaire, the time taken to interview a subject with respiratory symptoms is about half as long as that required using the MRC Questionnaire. On average the former takes about $2 \frac{1}{2}$ minutes and the latter about 5 minutes. The difference in the time required for a subject without respiratory symptoms is less pronounced, although the MRC Questionnaire still takes somewhat longer.

\section{The Design of The Trial}

The main objectives of the trial may be summarized briefly as follows:

(a) To compare the replies given to the two questionnaires by a population representative of that to which the PFR Questionnaire is normally applied.

(b) To measure the inter- and intra-observer error in applying the two questionnaires, the consistency of the replies over a period of about 6 months being of particular interest.

(c) To examine the relation between the replies given to the two questionnaires and objective measurements of pulmonary function.

In order to avoid having to examine an unduly high proportion of men without respiratory symptoms of any kind, it was decided to carry out the trial at one of the PFR selected collieries at which the prevalence of respiratory symptoms was known to be relatively high, and a colliery in the steam coal area of South Wales (which had previously been surveyed by the PFR in February, 1962) was chosen. The need to study the consistency of symptoms over a period of time meant that the trial was carried out in two stages, the first in October, 1963, and the second in May, 1964. These particular months of the year were chosen in order to reduce the possibility of seasonal variations in the prevalence of respiratory symptoms and in ventilatory function (Morgan, Pasqual, and Ashford, 1964).

The first stage of the trial lasted for one week and as many of the men working at the colliery who could be persuaded to come forward during that period were examined, the following observations being made on each man:

(a) Record of respiratory symptoms and smoking habits, using the MRC Shorter Questionnaire.

(b) Record of respiratory symptoms and smoking habits, using the PFR Questionnaire.

(c) Measurement of Forced Expiratory Ventilation $\left(\mathrm{FEV}_{1 \mathrm{sec}}\right)$ and Forced Vital Capacity (FVC), using a modified form of the Gaensler apparatus (Ashford, Forwell, and Routledge, 1960).

(d) Examination of 1-hour sputum samples, the subject being asked to collect all the phlegm produced from the chest during the first hour after getting out of bed on each of the two days succeeding the examination.

The MRC Questionnaire was applied by one or other of two doctors (Observers A and B) from St. Thomas's Hospital Medical School, London, both of whom are experienced in its use in epidemiological studies. The PFR Questionnaire was applied by one or other of the two observers (Observers C and D), who have been responsible for this aspect of the PFR medical surveys during the past 5 years. As each subject answered both questionnaires it was possible to determine to what extent the application of the first questionnaire had affected the answers given to the second. The choice of which questionnaire should be asked of each subject first and of which observer should apply the PFR Questionnaire and which should apply the MRC Questionnaire was made according to a random allocation.

The volume of sputum expectorated in the first hour after rising measured in field studies of chronic bronchitis has been found to correlate well with subjective and objective indices of the subject's condition (Elmes, Dutton, and Fletcher, 1959; Fletcher and Tinker, 1961). The day-to-day variation in the first-hour sputum volume and its relationship to the 24-hour volume have been studied by Ashcroft 
(1965) and Miller, Tinker, and Fletcher (1965). Visual classification of sputum purulence was carried out using the scale adopted by Miller (1963):

M1 = pure mucoid specimen with no suspicion of pus.

M2 - predominantly mucoid specimen with a suspicion of pus.

P1 - pus amounting to less than one-third of the specimen.

P2 $=$ pus amounting to between one and two-thirds of the specimen.

P3 - pus amounting to more than two-thirds of the specimen.

The volume and type of each sputum sample were assessed in duplicate by one of the doctors from St. Thomas's Hospital Medical School (Observer A) and a doctor from the PFR (Observer E).

The second stage of the trial also lasted for one week and as many as possible of the men who had come forward for the first stage were re-examined. The procedures applied were exactly the same as those at the first stage, retaining the original order of examination and observers for any given individual.

Thus the design of the trial allows a comparison to be made between the results obtained by pairs of experienced observers using each of the questionnaires and also between the results obtained by the same observer under the same conditions over a period of 6 months. The measurements of $F E V_{1 \mathrm{sec}}$, FVC, and 1-hour sputum volumes provide a standard against which the replies given on the two questionnaires may be assessed.

\section{The Men Examined}

In all a total of 357 men came forward for examination at the first stage of the trial and 286 of this group were re-examined at the second stage. In the interests of clarity of presentation, the analysis given in this first part of the paper is based largely upon the men who were examined on both occasions. The results relating to the men examined at the first stage of the trial only have also been analysed, but as they follow similar trends to those for the remainder of the population and as the numbers involved are relatively small, it was not thought worthwhile to present them separately for consideration.

Because of the random allocation, it was not possible to obtain an exact balance in terms of total numbers or age distributions between the various combinations of order of examination and observer. However, an analysis of the results obtained has shown that the random allocation has resulted in a reasonably uniform distribution of subjects. Such differences as exist are of moderate magnitude. and are unlikely to have any gross effect on a comparison between different observers or between the groups to whom the PFR Questionnaire and the MRC Questionnaire were applied first (Table I).

TABLE I

AGE DISTRIBUTION OF THE MEN EXAMINED AT BOTH STAGES OF THE TRIAL IN TERMS OF OBSERVER AND ORDER OF EXAMINATION

\begin{tabular}{|c|c|c|c|c|c|c|c|c|c|c|c|c|}
\hline \multirow{3}{*}{$\begin{array}{l}\text { Order } \\
\text { of } \\
\text { Exam- } \\
\text { ination }\end{array}$} & \multicolumn{2}{|c|}{ Observer } & \multicolumn{10}{|c|}{ Age Group (yrs) } \\
\hline & & & \multicolumn{2}{|c|}{-39} & \multicolumn{2}{|c|}{$40-49$} & \multicolumn{2}{|c|}{$50-59$} & \multicolumn{2}{|c|}{$60-64$} & \multicolumn{2}{|c|}{ All } \\
\hline & MRC & PFR & No & $\begin{array}{l}\text { Per } \\
\text { cent. }\end{array}$ & No. & $\begin{array}{l}\text { Per } \\
\text { cent. }\end{array}$ & No. & $\begin{array}{l}\text { Per } \\
\text { cent }\end{array}$ & No. & $\begin{array}{l}\text { Per } \\
\text { cent. }\end{array}$ & No. & $\begin{array}{l}\text { Per } \\
\text { cent. }\end{array}$ \\
\hline \multirow{3}{*}{$\begin{array}{l}\text { PFR } \\
\text { First }\end{array}$} & $\mathbf{A}$ & $\begin{array}{c}\text { C } \\
\text { D } \\
\text { Both }\end{array}$ & & $\begin{array}{l}29 \\
39 \\
34\end{array}$ & $\begin{array}{r}12 \\
3 \\
15\end{array}$ & $\begin{array}{l}35 \\
10 \\
23\end{array}$ & $\begin{array}{r}6 \\
11 \\
17\end{array}$ & $\begin{array}{l}18 \\
35 \\
26\end{array}$ & $\begin{array}{r}6 \\
5 \\
11\end{array}$ & $\begin{array}{l}18 \\
16 \\
17\end{array}$ & $\begin{array}{l}34 \\
31 \\
65\end{array}$ & $\begin{array}{l}12 \\
11 \\
23\end{array}$ \\
\hline & B & $\underset{\text { Both }}{\text { C }}$ & & $\begin{array}{l}39 \\
41 \\
40\end{array}$ & $\begin{array}{l}13 \\
11 \\
24\end{array}$ & $\begin{array}{l}30 \\
28 \\
29\end{array}$ & $\begin{array}{l}10 \\
10 \\
20\end{array}$ & $\begin{array}{l}23 \\
26 \\
24\end{array}$ & $\begin{array}{l}4 \\
2 \\
6\end{array}$ & $\begin{array}{l}9 \\
5 \\
7\end{array}$ & $\begin{array}{l}44 \\
39 \\
83\end{array}$ & $\begin{array}{l}15 \\
14 \\
29\end{array}$ \\
\hline & Both & $\begin{array}{c}\text { C } \\
\text { Doth }\end{array}$ & & $\begin{array}{l}35 \\
40 \\
37\end{array}$ & $\begin{array}{l}25 \\
14 \\
39\end{array}$ & $\begin{array}{l}32 \\
20 \\
26\end{array}$ & $\begin{array}{l}16 \\
21 \\
37\end{array}$ & $\begin{array}{l}21 \\
30 \\
25\end{array}$ & $\begin{array}{r}10 \\
7 \\
17\end{array}$ & $\begin{array}{l}13 \\
10 \\
11\end{array}$ & $\begin{array}{r}78 \\
70 \\
148\end{array}$ & $\begin{array}{l}27 \\
25 \\
52\end{array}$ \\
\hline \multirow{3}{*}{$\begin{array}{l}\text { MRC } \\
\text { First }\end{array}$} & A & $\underset{\text { Both }}{\stackrel{\text { C }}{\text { D }}}$ & & $\begin{array}{l}31 \\
29 \\
30\end{array}$ & $\begin{array}{l}10 \\
13 \\
23\end{array}$ & $\begin{array}{l}28 \\
46 \\
36\end{array}$ & $\begin{array}{r}14 \\
5 \\
19\end{array}$ & $\begin{array}{l}34 \\
18 \\
30\end{array}$ & $\begin{array}{l}1 \\
2 \\
3\end{array}$ & $\begin{array}{l}3 \\
7 \\
5\end{array}$ & $\begin{array}{l}36 \\
28 \\
64\end{array}$ & $\begin{array}{l}13 \\
10 \\
22\end{array}$ \\
\hline & B & $\underset{\text { Both }}{\mathrm{C}}$ & & $\begin{array}{l}32 \\
37 \\
35\end{array}$ & $\begin{array}{r}6 \\
12 \\
18\end{array}$ & $\begin{array}{l}19 \\
28 \\
24\end{array}$ & $\begin{array}{l}11 \\
12 \\
23\end{array}$ & $\begin{array}{l}35 \\
28 \\
31\end{array}$ & $\begin{array}{l}4 \\
3 \\
7\end{array}$ & $\begin{array}{r}13 \\
7 \\
9\end{array}$ & $\begin{array}{l}31 \\
43 \\
74\end{array}$ & $\begin{array}{l}11 \\
15 \\
268\end{array}$ \\
\hline & Both & $\underset{\text { Both }}{\text { C }}$ & $\begin{array}{l}21 \\
24 \\
45\end{array}$ & $\begin{array}{l}31 \\
34 \\
33\end{array}$ & $\begin{array}{l}16 \\
25 \\
41\end{array}$ & $\begin{array}{l}24 \\
35 \\
30\end{array}$ & $\begin{array}{l}25 \\
17 \\
42\end{array}$ & $\begin{array}{l}37 \\
24 \\
30\end{array}$ & $\begin{array}{r}5 \\
5 \\
10\end{array}$ & $\begin{array}{l}7 \\
7 \\
7\end{array}$ & $\begin{array}{r}67 \\
71 \\
138\end{array}$ & $\begin{array}{l}23 \\
25 \\
48\end{array}$ \\
\hline \multirow{3}{*}{ Both } & A & $\underset{\text { Both }}{\text { C }}$ & & $\begin{array}{l}30 \\
34 \\
32\end{array}$ & $\begin{array}{l}22 \\
16 \\
38\end{array}$ & $\begin{array}{l}31 \\
27 \\
29\end{array}$ & $\begin{array}{l}20 \\
16 \\
36\end{array}$ & $\begin{array}{l}29 \\
27 \\
28\end{array}$ & $\begin{array}{r}7 \\
7 \\
14\end{array}$ & $\begin{array}{l}10 \\
12 \\
11\end{array}$ & $\begin{array}{r}70 \\
59 \\
129\end{array}$ & $\begin{array}{l}25 \\
21 \\
45\end{array}$ \\
\hline & B & $\begin{array}{c}\text { C } \\
\text { D } \\
\text { Both }\end{array}$ & $\begin{array}{l}27 \\
32 \\
59\end{array}$ & $\begin{array}{l}36 \\
39 \\
38\end{array}$ & $\begin{array}{l}19 \\
23 \\
42\end{array}$ & $\begin{array}{l}25 \\
28 \\
27\end{array}$ & $\begin{array}{l}21 \\
22 \\
43\end{array}$ & $\begin{array}{l}28 \\
27 \\
27\end{array}$ & $\begin{array}{r}8 \\
5 \\
13\end{array}$ & $\begin{array}{r}11 \\
6 \\
8\end{array}$ & $\begin{array}{r}75 \\
82 \\
157\end{array}$ & $\begin{array}{l}26 \\
29 \\
55\end{array}$ \\
\hline & Both & $\begin{array}{c}\text { C } \\
\text { D } \\
\text { Both }\end{array}$ & $\begin{array}{r}48 \\
52 \\
100\end{array}$ & $\begin{array}{l}33 \\
37 \\
35\end{array}$ & $\begin{array}{l}41 \\
39 \\
80\end{array}$ & $\begin{array}{l}28 \\
28 \\
28\end{array}$ & $\begin{array}{l}41 \\
38 \\
79\end{array}$ & $\begin{array}{r}28 \\
27 \\
28\end{array}$ & $\begin{array}{l}15 \\
12 \\
27\end{array}$ & $\begin{array}{r}10 \\
9 \\
9\end{array}$ & $\begin{array}{l}145 \\
141 \\
286\end{array}$ & $\begin{array}{r}51 \\
49 \\
100\end{array}$ \\
\hline
\end{tabular}

Apart from a slight deficiency amongst the younger men, the age distribution of the subjects examined is representative of the overall working population of about 1,000 men at the colliery. The men to whom the MRC Questionnaire was applied first were slightly older on average than those to whom the PFR Questionnaire was applied first. In addition, the men examined by Observer A were slightly older than those examined by Observer $B$ and the men examined by Observer $C$ were slightly older than those examined by Observer $D$.

As far as smoking habits are concerned, the proportion of smokers assessed on the basis of the replies given to the PFR Questionnaire amongst the men to whom the MRC Questionnaire was applied first is similar to that amongst the men to whom the PFR Questionnaire was applied first. On the other hand, the proportion of non-smokers in the former 
group is slightly higher and the proportion of exsmokers is slightly lower than in the latter. Observer A interviewed a slightly lower porportion of smokers and a slightly higher proportion of ex-smokers than Observer B, whereas Observer C interviewed a slightly lower proportion of non-smokers and a slightly higher proportion of ex-smokers than Observer D. The overall proportion of smokers amongst the men examined (68 per cent.) was about 10 per cent. lower than the average figure for the colliery and the overall proportions of non-smokers and ex-smokers were correspondingly higher.

A further analysis of the characteristics of the men examined at both stages has been made in terms of the $F E V_{1 \mathrm{sec}}$ measurements recorded at the second stage of the trial. The average $F_{E V}$ sec of the men to whom the PFR Questionnaire was applied first is about 0.05 litre higher than that of the men to whom the MRC Questionnaire was applied first, and a similar difference also exists between the men examined by Observer C and Observer D. In these instances this slight difference in average ventilatory function is probably a reflection of corresponding differences in age distribution. On the other hand the $\mathrm{FEV}_{1 \mathrm{sec}}$ of the men examined by Observer A was higher than that of the men examined by Observer B, although the former group were slightly older than the latter. When the sub-division in terms of smoking habits is considered, the figures for the smokers follow the same trends as those for the whole group, whereas those for the non-smokers and ex-smokers show a greater degree of variation.

The mean sputum volumes of the first specimens returned at the first stage of the trial, as assessed by Observer E, were also assessed in terms of order of examination and smoking habits. The average sputum volume of the men to whom the PFR Questionnaire was applied first was slightly lower than that of the men to whom the MRC Questionnaire was applied first. This corresponds to the differences in age distribution and $\mathrm{FEV}_{1 \mathrm{sec}}$ noted previously. There are also slight differences between the sputum volumes returned by the men examined by the two PFR observers and by the two MRC observers. The overall figures show that the amount of sputum produced by the non-smokers was, on average, very much less than that produced by the smokers and ex-smokers.

VARIATION IN Recording RESPIRATORY SyMPTOMS AND SMOKING Habits USING THE PFR QUESTIONNAIRE

The prevalence of the individual respiratory symptoms recorded by Observers $C$ and $D$ at the two stages of the trial using the PFR Questionnaire is shown in Table II, where significant $(P<0.05)$ differences are indicated between the two observers (for given order of examination and stage), between the men examined first by the PFR and the men examined first by the MRC (for given observer and

TABLE II

PREVALENCE (PER CENT.) OF RESPIRATORY SYMPTOMS USING THE PFR QUESTIONNAIRE AMONGST THE MEN EXAMINED AT BOTH STAGES OF THE TRIAL

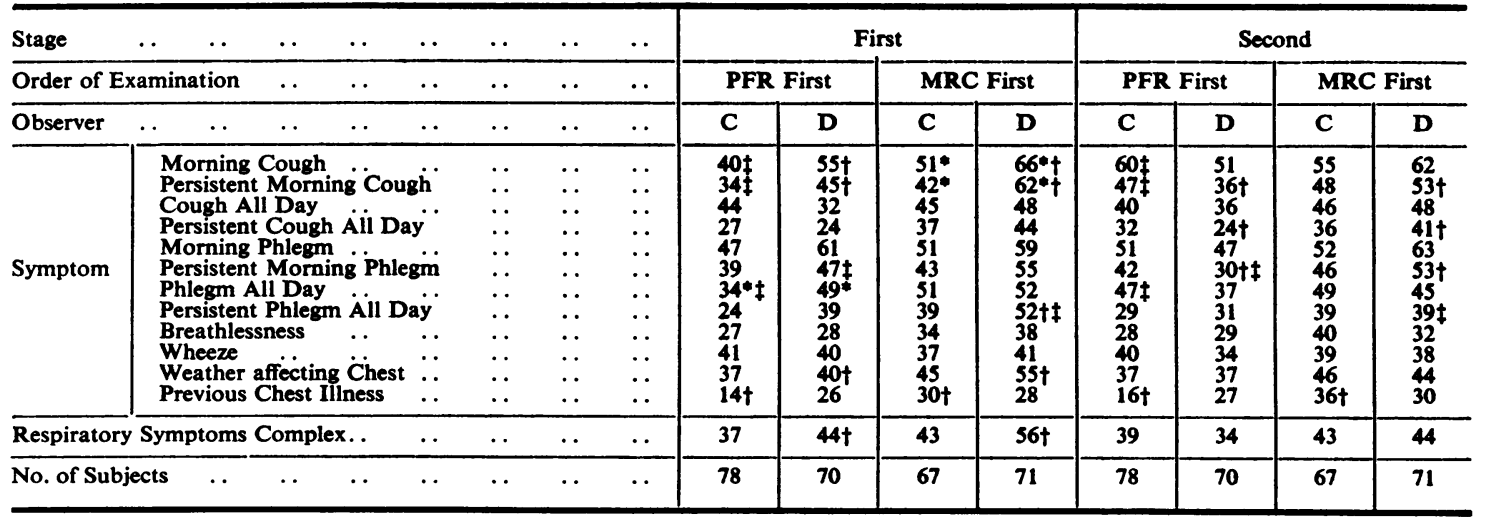

* Significant difference between the two observers.

+ Significant differences between the men examined first by PFR and by MRC.

$\$$ Significant difference between the two stages.

$\S$ Ideally, any assessment of the significance of the difference between corresponding sets of results should take account of the fact that a complex of individual symptoms is assessed for each subject. This presents some complicated statistical problems which are outside the scope of the present study (Ashford, Forwell, and Routledge, to be published). For the present purposes each comparison has been assessed separately and the resulting significance levels, although unlikely to be exact, provide a useful guide to the existence of real difierence in prevalence. 
stage), and between the two stages (for given order of examination and observer). The prevalence of respiratory symptoms amongst the men to whom the PFR Questionnaire was applied first was generally lower than amongst the men to whom the MRC Questionnaire was applied first. This tendency is apparent at both stages of the trial and is particularly marked for Observer D. Although different groups of men were involved, the subjects examined first by the MRC being slightly older and having on average slightly lower $\mathrm{FEV}_{1 \mathrm{sec}}$ and slightly higher sputum volumes, the differences are sufficiently large to suggest that the prevalence of symptoms recorded using the PFR Questionnaire was enhanced by the prior application of the MRC Questionnaire. At the first stage of the trial, the men examined by Observer $C$ reported a lower proportion of respiratory symptoms than those examined by Observer D, but at the second stage there were no consistent differences.

Exactly the same procedures were followed at the two stages of the trial in terms of order of examination and questioner; the variability of the replies given to the PFR Questionnaire is illustrated at Table III, which shows the proportion of men giving consistent answers to each of the individual questions. The general level of agreement amongst the men to whom the MRC Questionnaire was applied first was slightly better than that amongst the men to whom the PFR Questionnaire was applied first. There is, however, little to choose between the two observers in this respect. On average, consistent replies were given by rather more than 80 per cent. of the subjects. There is little variation between the different symptoms, apart from a comparatively low result for the question about cough all day amongst the men to whom the PFR Questionnaire was applied first.

TABLE III

CONSISTENCY (PER CENT.) OF REPLIES GIVEN TO PFR QUESTIONNAIRE AT THE TWO STAGES OF THE TRIAL

\begin{tabular}{|c|c|c|c|c|c|c|c|c|c|}
\hline \multicolumn{2}{|c|}{ Order of Examination } & \multirow{2}{*}{$\frac{\cdots}{\ldots}$} & \multirow{2}{*}{$\frac{}{\ldots}$} & \multirow{2}{*}{ 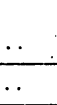 } & \multirow{2}{*}{$\frac{\cdots}{\ldots}$} & \multicolumn{2}{|c|}{$\begin{array}{l}\text { PFR } \\
\text { First }\end{array}$} & \multicolumn{2}{|c|}{$\begin{array}{l}\text { MRC } \\
\text { First }\end{array}$} \\
\hline Observer. & . & & & & & C & $\mathbf{D}$ & $\mathbf{C}$ & D \\
\hline Symptom & $\begin{array}{l}\text { Morning } \\
\text { Persistent } \\
\text { Cough Al } \\
\text { Persistent } \\
\text { Morning I } \\
\text { Persistent } \\
\text { Phlegm A } \\
\text { Persistent } \\
\text { Breathless } \\
\text { Wheeze } \\
\text { Weather a } \\
\text { Previous C }\end{array}$ & $\begin{array}{l}\text { Cous } \\
\text { Mor } \\
\text { I Da } \\
\text { Cou } \\
\text { Phle } \\
\text { Mor } \\
\text { Mo } \\
\text { Phle } \\
\text { sness } \\
\text { affect } \\
\text { Ches }\end{array}$ & $\begin{array}{l}\text { ing Coug } \\
\text { Äll Daj } \\
\text { n. } \\
\text { ing Phleg } \\
\ldots \\
\ldots \\
\ldots \\
\text { IIIness }\end{array}$ & 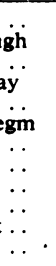 & $\begin{array}{l}\cdots \\
\because \\
\because \\
\because \\
\cdots\end{array}$ & $\begin{array}{l}80 \\
81 \\
66 \\
77 \\
77 \\
77 \\
89 \\
87 \\
87 \\
84 \\
86 \\
87\end{array}$ & $\begin{array}{l}82 \\
85 \\
72 \\
82 \\
77 \\
87 \\
68 \\
78 \\
85 \\
85 \\
90 \\
89\end{array}$ & $\begin{array}{l}72 \\
79 \\
90 \\
90 \\
81 \\
88 \\
84 \\
82 \\
85 \\
90 \\
81 \\
82\end{array}$ & $\begin{array}{l}90 \\
80 \\
83 \\
86 \\
87 \\
76 \\
79 \\
76 \\
83 \\
83 \\
86 \\
79\end{array}$ \\
\hline \multicolumn{4}{|c|}{ Respiratory Symptom Complex } & $\cdots$ & . & 86 & 82 & 91 & 85 \\
\hline \multicolumn{2}{|c|}{ No. of Subjects } & $\cdots$ & & & & 78 & 70 & 67 & 71 \\
\hline
\end{tabular}

When the replies to the questions about smoking $D$ habits at the first and second stages of the trial were compared, there was a high degree of consistency $\frac{3}{1}$ between the two sets of results. As far as the classi-? fication in terms of smoker, non-smoker, and ex- $\overrightarrow{\vec{F}}$ smoker is concerned, only four out of the 286 men examined gave answers which were inconsistent $\frac{\mathrm{C}}{5}$ under the coding convention and almost all the $\frac{\bar{c}}{\frac{5}{b}}$ population were classified in the same way on the $\frac{\widetilde{\Phi}}{\widehat{D}}$ two occasions. An equally satisfactory level of $\frac{\Omega}{0}$ agreement was observed in the reported consumption कs of tobacco. In view of the generally high level of $\overrightarrow{0}$ reproducibility of the replies to the questions about $\overrightarrow{-}$ smoking habits, it is considered that the minor $\vec{\sigma}$ differences between different observers and the two orders of examination are probably a fair reflection $\stackrel{\rho}{\zeta}$ of real variations between the groups examined.

VARIATION IN RECORDING RESPIRATORY SYMPTOMS AND SMOKING HABITS USING THE MRC QUESTONS NAIRE

The prevalence of respiratory symptoms reported $\vec{\nabla}$ by Observers A and B using the MRC Questionnaire is shown in Table IV (opposite) which follows the same general form as Table II. Besides the informa- $\mathscr{\theta}$ tion about individual symptoms, an assessment of ? the symptom complex in terms of "persistent coug and sputum", Grade 1 (Higgins, Cochrane, Gilso o and Wood, 1959), "chronic bronchitis" (Higgins, 1957), "simple chronic bronchitis" (Fletcher and others, 1959), and the "chronic bronchitis syndrome" $\stackrel{8}{\complement}$ (College of General Practitioners, 1961) has also $\underset{\vec{F}}{\overrightarrow{2}}$ been included in this Table. When the results are $\frac{0}{3}$ considered in terms of order of examination, the prevalences of the individual symptoms for the subjects to whom the MRC Questionnaire was applied first are generally higher than the corres- $\stackrel{\bigcirc}{\frac{\rho}{3}}$ ponding results for the subjects to whom the PFR Questionnaire was applied first. These differences are considerably more pronounced for the men examined $\delta$ by Observer $B$ than for the men examined by Observer A. Although the general direction of the $\mathrm{O}$ trend corresponds to the differences in age distribution, $\mathrm{FEV}_{1 \mathrm{sec}}$, and sputum volume, the magnitude $\frac{\mathrm{D}}{2}$ of the discrepancy suggests that the application of the PFR Questionnaire tended to reduce the pre- $\sigma$ valence of respiratory symptoms reported subse- $N$ quently using the MRC Questionnaire. When the N results obtained by the two observers are compared ${ }_{\sigma}^{\omega}$ there is a general tendency for the prevalence of symptoms reported by Observer A to be lower than $\frac{0}{\Phi}$ the corresponding results for the men examined by Observer B, although this is by no means always the case. On the whole the corresponding results obtained on the two stages of the trial are in good agreement. 
TABLE IV

PREVALENCE (PER CENT.) OF RESPIRATORY SYMPTOMS USING THE MRC QUESTIONNAIRE AMONGST MEN EXAMINED AT BOTH STAGES OF THE TRIAL

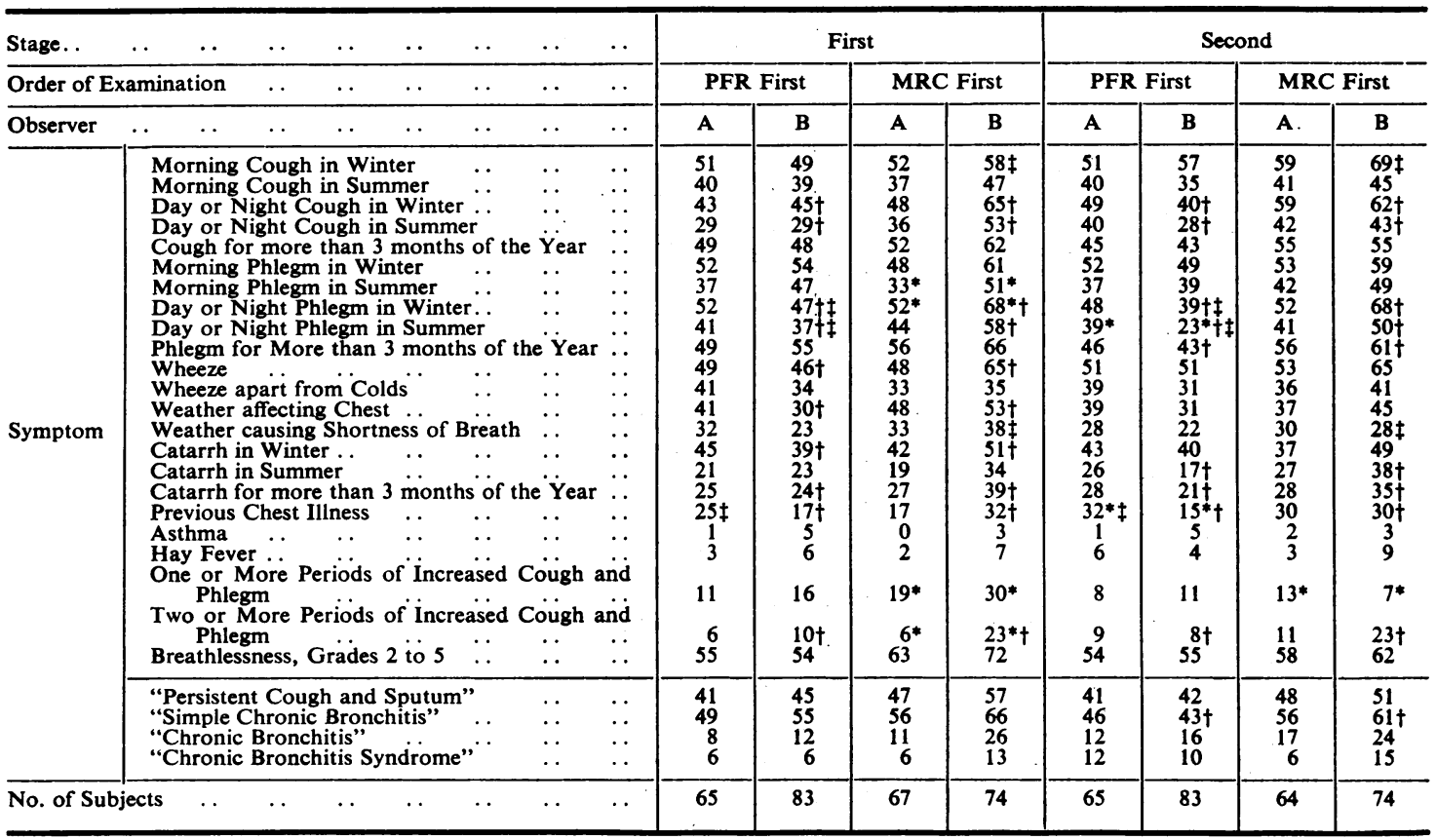

* Significant difference between the two observers.

† Significant difference between the men examined first by PFR and MRC

$¥$ Significant difference between the two stages.

$\S$ See footnote to Table II.

The consistency of the replies given to the MRC Questionnaire is shown at Table V (overleaf ). There is little difference between the results obtained by the two observers, although the replies given by the men examined by Observer A were in slightly better agreement than the corresponding results for the men examined by Observer B. The overall level of consistency is in the region of 80 per cent., much the same as that for the PFR Questionnaire.

The replies to the questions about smoking habits showed an equally high degree of consistency as the corresponding results for the PFR Questionnaire.

\section{SPUTUM AsSESSMENT}

Each subject was asked to collect 1-hour sputum samples on the two days following his examination at each stage of the trial. The volume and type of each specimen were then assessed in duplicate by Observer $\mathrm{E}$ and similar measurements were made on the majority of specimens by Observer A. The duplicate readings by the same observer for both volume and sputum type were in very good agreement, as were the readings by the two observers. As far as the assessments of volume are concerned, the small proportion of disagreements were almost all of $1 \mathrm{ml}$. only. An example of the consistency of the assessments of sputum type is given at Table VI (overleaf), which compares the first readings by Observers $\mathrm{A}$ and $\mathrm{E}$ at the first stage of the trial. In view of this close level of agreement, Observer E's first readings have been used as the basic measurement of sputum volume and type in the subsequent analysis.

At neither stage of the trial did all the men examined return the sputum specimens. At the first stage, 309 out of the 357 men examined returned two sputum specimens and twelve returned one specimen only. The corresponding figures for the second stage of the trial were that 267 out of 286 returned two specimens and three returned one specimen only. An examination of the ventilatory function measurements in terms of age and sputum volume (see Part II) suggests that the majority of the men who failed to return a specimen in fact produced no sputum. 
82 W.W.HOLLAND, J.R.ASHFORD, J.R.T.COLLEY, D.C.MORGAN, AND N.J.PEARSON

TABLE V

CONSISTENCY (PER CENT.) OF REPLIES TO THE MRC QUESTIONNAIRE AT BOTH STAGES OF THE TRIAL

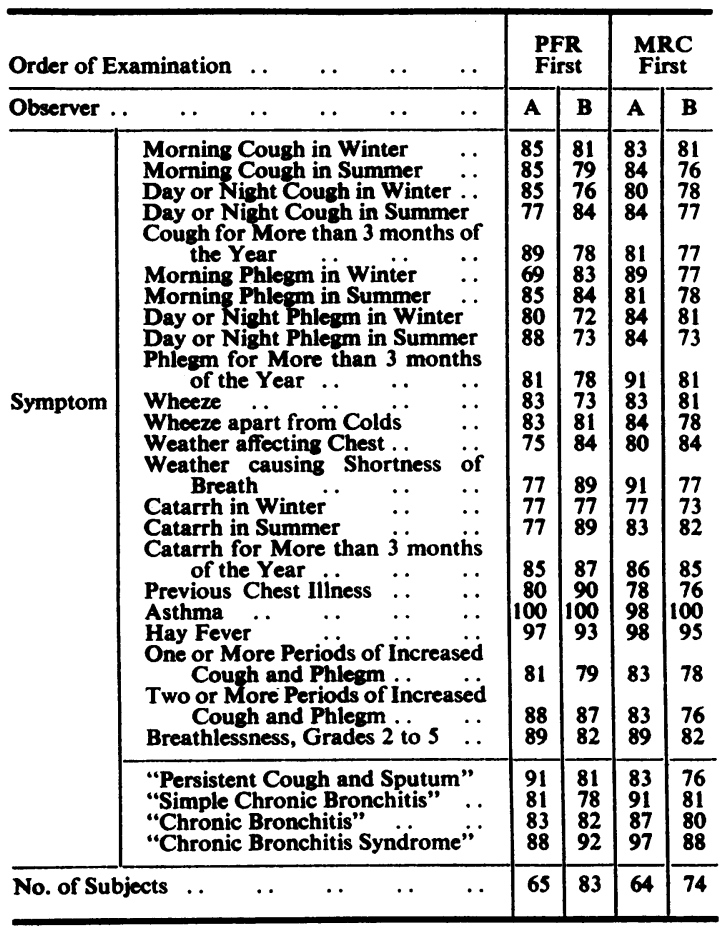

The sputum volumes of the first and second specimens collected at the two stages of the trial are compared at Table VII. Although about two-thirds of the men returned exactly the same volume on each occasion, the results show a considerable spread.
TABLE VI

COMPARISON OF ASSESSMENTS OF SPUTUM TYPE BY THE TWO OASERVERS AT THE SECOND STAGE OF THE THE TWO OBSERVERS AT THE SECOND STAGE
TRIAL, SHOWING NUMBER OF SPECIMENS

\begin{tabular}{|c|c|c|c|c|c|c|c|c|c|}
\hline \multirow{4}{*}{$\begin{array}{l}\text { Observer A } \\
\text { First } \\
\text { Reading }\end{array}$} & \multicolumn{9}{|c|}{ Observer E First Reading } \\
\hline & $\begin{array}{c}\text { Sputum } \\
\text { Type }\end{array}$ & M1 & $\mathbf{M} 2$ & $\mathbf{P 1}$ & P2 & P3 & Saliva & $\begin{array}{c}\text { No } \\
\text { Sputum }\end{array}$ & All \\
\hline & $\begin{array}{c}\text { M1 } \\
\text { M2 } \\
\text { P1 } \\
\text { P2 } \\
\text { P3 } \\
\text { Saliva } \\
\text { No Sputum }\end{array}$ & $\begin{array}{r}87 \\
9 \\
\end{array}$ & $\begin{array}{l}7 \\
6 \\
2\end{array}$ & 6 & 1 & & 1 & 293 & $\begin{array}{r}98 \\
15 \\
8 \\
1 \\
1 \\
293\end{array}$ \\
\hline & All & 96 & 15 & 6 & 1 & & 5 & 293 & 416 \\
\hline
\end{tabular}

At the first stage of the trial there is a tendency for the first specimen to have a slightly greater volume than the second, but at the second stage the average volumes are in close agreement. It is worth noting that very few of the men who had no sputum on one occasion had some sputum on the other. The type of sputum present in the two specimens was also reasonably consistent, although Table VIII (opposite) shows that there were some changes between grades M1 and M2.

The volumes of the sputum specimens returne $\$$ at the first and second stages of the trial are cont pared in Table IX (opposite). The individual resules show a considerable spread, but the average returns for the two stages are in good agreement. For the first specimen a higher proportion of men produced no sputum at the second stage than at the first, but this was balanced by a lower proportion who produced just $1 \mathrm{ml}$. Comparison of Tables VII and IX shows that the volumes of the two specimens produced

TABLE VII

COMPARISON OF SPUTUM, VOLUMES ON FIRST AND SECOND SPECIMENS AT OBSERVER E'S FIRST READING, SHOWING No. OF MEN IN EACH CATEGORY

\begin{tabular}{|c|c|c|c|c|c|c|c|c|c|c|c|c|c|c|c|c|c|c|c|c|c|}
\hline \multirow{2}{*}{$\begin{array}{l}\text { Stage } \\
\text { First } \\
\text { Specimen }\end{array}$} & \multirow{2}{*}{$\frac{\ldots}{\begin{array}{c}\text { Volume } \\
\text { (ml.) }\end{array}}$} & \multicolumn{10}{|c|}{ First } & \multicolumn{10}{|c|}{ Second } \\
\hline & & 0 & 1 & 2 & 3 & 4 & 5 & $6-10$ & $\begin{array}{c}\text { Over } \\
10\end{array}$ & $\begin{array}{c}\text { Not } \\
\text { Returned }\end{array}$ & All & 0 & 1 & 2 & 3 & 4 & 5 & $6-10$ & $\begin{array}{c}\text { Over } \\
10\end{array}$ & $\begin{array}{c}\text { Not } \\
\text { Returned }\end{array}$ & All \\
\hline \multirow{10}{*}{$\begin{array}{l}\text { Second } \\
\text { Specimen }\end{array}$} & o & 140 & 10 & 10 & 3 & 2 & 2 & 1 & 1 & & 169 & 137 & 2 & 3 & & 1 & 3 & 1 & 1 & & 148 \\
\hline & 1 & 5 & 20 & 7 & 1 & 1 & 1 & & & & 35 & 5 & 4 & 9 & 1 & & & & & & 19 \\
\hline & 2 & 2 & 4 & 7 & 4 & 5 & & 3 & & & 25 & 4 & 1 & 16 & 4 & 1 & 1 & 1 & & & 28 \\
\hline & 3 & 2 & 4 & 5 & 10 & 3 & 3 & & & & 27 & 2 & & 10 & 8 & 2 & & 3 & & & 25 \\
\hline & 4 & 1 & & 2 & 2 & 4 & & 3 & & & 12 & 1 & & 1 & 5 & 2 & & 2 & & & 11 \\
\hline & 5 & & 1 & & 1 & 1 & 1 & 5 & & & 9 & 1 & & 1 & 1 & 3 & 2 & 3 & & & 11 \\
\hline & 6-10 & 4 & & & 2 & 1 & 6 & 9 & 2 & & 24 & 1 & 1 & & 2 & 4 & 2 & 8 & 2 & & 20 \\
\hline & Over 10 & & & & & & 1 & 2 & 5 & & 8 & & & & & & 1 & 2 & 2 & & 5 \\
\hline & Not Returned & 5 & 1 & 1 & 3 & 1 & 1 & & & 36 & 48 & 1 & & 1 & & & & 1 & & 16 & 19 \\
\hline & All & 159 & 40 & 32 & 26 & 18 & 15 & 23 & 8 & 36 & 357 & 152 & 8 & 41 & 21 & 13 & 9 & 21 & 5 & 16 & 286 \\
\hline
\end{tabular}


TABLE VIII

COMPARISON OF SPUTUM TYPE ON FIRST AND SECOND SPECIMENS AT OBSERVER E'S FIRST READING, SHOWING No. OF MEN IN EACH CATEGORY

\begin{tabular}{|c|c|c|c|c|c|c|c|c|c|c|c|c|c|c|c|c|c|c|c|}
\hline \multirow{2}{*}{$\begin{array}{l}\text { Stage } \\
\text { First } \\
\text { Specimen }\end{array}$} & \multirow{2}{*}{$\begin{array}{ll}\text {. } & \ldots \\
\text { Type }\end{array}$} & \multicolumn{9}{|c|}{ First } & \multicolumn{9}{|c|}{ Second } \\
\hline & & M1 & M2 & P1 & P2 & P3 & Saliva & $\begin{array}{c}\text { No } \\
\text { Sputum }\end{array}$ & $\begin{array}{c}\text { Not } \\
\text { Returned }\end{array}$ & All & MI & M2 & P1 & P2 & P3 & Saliva & $\begin{array}{c}\text { No } \\
\text { Sputum }\end{array}$ & $\begin{array}{c}\text { Not } \\
\text { Returned }\end{array}$ & All \\
\hline \multirow{9}{*}{$\begin{array}{l}\text { Second } \\
\text { Specimen }\end{array}$} & M1 & 71 & 13 & 8 & & & 1 & 11 & & 104 & 70 & 5 & & 1 & & 1 & 12 & & 89 \\
\hline & M2 & 9 & 3 & 1 & & & & 1 & & 14 & 8 & 3 & 3 & & & & & & 14 \\
\hline & P1 & 3 & 3 & 7 & & & & 1 & & 14 & 2 & & 5 & & & & & & 7 \\
\hline & P2 & & & & 3 & & & & & 3 & & & & 2 & & & & & 2 \\
\hline & P3 & & & & & & & & & & & & & & & & & & \\
\hline & Saliva & 2 & 1 & & & & 3 & & & 6 & 3 & & & & & 2 & 2 & & 7 \\
\hline & No Sputum & 20 & 9 & & & & & 139 & & 168 & 11 & & & & & & 137 & & 148 \\
\hline & Not Returned & 5 & 1 & 1 & & & & 5 & 36 & 48 & 1 & & 1 & & & & 1 & 16 & 19 \\
\hline & All & 110 & 30 & 17 & 3 & & 4 & 157 & 36 & 357 & 95 & 8 & 9 & 3 & & 3 & 152 & 16 & 286 \\
\hline
\end{tabular}

TABLE IX

COMPARISON OF SPUTUM VOLUMES AT THE FIRST AND SECOND STAGES OF THE TRIAL AT OBSERVER E'S FIRST READING, SHOWING No. OF MEN IN EACH CATEGORY

\begin{tabular}{|c|c|c|c|c|c|c|c|c|c|c|c|c|c|c|c|c|c|c|c|c|c|}
\hline \multirow{2}{*}{$\begin{array}{l}\text { Specimen } \\
\text { First } \\
\text { Stage }\end{array}$} & \multirow{2}{*}{$\frac{\ldots}{\substack{\text { Volume } \\
\text { (ml.) }}}$} & \multicolumn{10}{|c|}{ First } & \multicolumn{10}{|c|}{ Second } \\
\hline & & 0 & 1 & 2 & 3 & 4 & 5 & $6-10$ & $\begin{array}{c}\text { Over } \\
10\end{array}$ & $\begin{array}{c}\text { Not } \\
\text { Returned }\end{array}$ & All & $\mathbf{0}$ & 1 & 2 & 3 & 4 & 5 & $6-10$ & $\begin{array}{c}\text { Over } \\
10\end{array}$ & $\begin{array}{c}\text { Not } \\
\text { Returned }\end{array}$ & All \\
\hline \multirow{10}{*}{$\begin{array}{l}\text { Second } \\
\text { Stage }\end{array}$} & 0 & 105 & 9 & 10 & 1 & 5 & 3 & 2 & 1 & 16 & 152 & 106 & 9 & 3 & 5 & 2 & & 2 & 1 & 20 & 148 \\
\hline & 1 & 1 & 4 & 2 & & & & 1 & & & 8 & 5 & 5 & 5 & 3 & & & & & 1 & 19 \\
\hline & 2 & 7 & 16 & 6 & 9 & & & 2 & & 1 & 41 & 6 & 7 & 4 & 4 & & 3 & 1 & & 3 & 28 \\
\hline & 3 & 2 & 3 & 3 & 3 & 5 & & 2 & 1 & 2 & 21 & 7 & 4 & 5 & 3 & 2 & 2 & & & 2 & 25 \\
\hline & 4 & 2 & 1 & 3 & 2 & 2 & & 3 & & & 13 & & & 2 & 4 & 1 & 1 & 3 & & & 11 \\
\hline & 5 & & & & 3 & 1 & 3 & 2 & & & 9 & 3 & 1 & & 2 & 2 & 1 & 2 & & & 11 \\
\hline & $6-10$ & 3 & & 2 & 4 & 1 & 3 & 5 & 3 & & 21 & 2 & 1 & 3 & 1 & 3 & & 7 & 3 & & 20 \\
\hline & Over 10 & 1 & & & & & 1 & 1 & 2 & & 5 & 1 & & & & & & 2 & 1 & 1 & 5 \\
\hline & Not Returned & 6 & 1 & 1 & 1 & & & 1 & & 6 & 16 & 6 & 1 & & 1 & 1 & 1 & 2 & 1 & 6 & 19 \\
\hline & All & 127 & 34 & 27 & 23 & 14 & $\overline{10}$ & 19 & 7 & 25 & 286 & 136 & 28 & 22 & 23 & 11 & 8 & 19 & 6 & 33 & 286 \\
\hline
\end{tabular}

at each stage (i.e. after an interval of 1 day) were more consistent than the volumes of the first and second specimens produced at the two stages (i.e. after an interval of 6 months). The difference in level of agreement is very highly significant. The assessments of sputum type (Table X, overleaf) at the two stages of the trial show similar trends to those of sputum volume.

\section{COMMENT}

The results of this analysis suggest that the replies given to the questions about respiratory symptoms using either questionnaire may have been affected by the fact that the other questionnaire had been applied a few minutes earlier. The possibility of an effect of this kind had been anticipated when the trial was planned and is consistent with experience in other types of inquiry (Payne, 1951). For this reason the further analysis of the replies to the questions about respiratory symptoms given in Part II of this paper has been based solely upon the results of the first questionnaire asked of each subject.

Certain differences were noted between the replies given to the two observers using the PFR Questionnaire and also between those given to the two observers using the MRC Questionnaire. Although the variation may have been to some extent due to the fact that different groups of subjects were examined, it is possible that a subjective effect on the part of the questioner may also have been involved. However, the extent of any such tendency must have been small and in the further analysis of 
TABLE $\mathbf{X}$

COMPARISON OF SPUTUM TYPE AT THE FIRST AND SECOND STAGES OF THE TRIAL AT OBSERVER E'S FIRST READING, SHOWING No. OF MEN IN EACH CATEGORY

\begin{tabular}{|c|c|c|c|c|c|c|c|c|c|c|c|c|c|c|c|c|c|c|c|}
\hline \multirow{2}{*}{$\begin{array}{l}\text { Specimen } \\
\text { First } \\
\text { Stage }\end{array}$} & \multirow{2}{*}{$\begin{array}{ll}\cdots & \cdots \\
\text { Type }\end{array}$} & \multicolumn{9}{|c|}{ First } & \multicolumn{9}{|c|}{ Second } \\
\hline & & M1 & M2 & P1 & P2 & P3 & Saliva & $\begin{array}{c}\text { No } \\
\text { Sputum }\end{array}$ & $\begin{array}{c}\text { Not } \\
\text { Returned }\end{array}$ & All & M1 & M2 & P1 & $\mathbf{P 2}$ & P3 & Saliva & $\begin{array}{c}\text { No } \\
\text { Sputum }\end{array}$ & $\begin{array}{c}\text { Not } \\
\text { Returned }\end{array}$ & All \\
\hline \multirow{9}{*}{$\begin{array}{l}\text { Second } \\
\text { Stage }\end{array}$} & M1 & 60 & 11 & 8 & 8 & & 1 & 12 & 3 & 95 & 50 & 8 & 4 & 1 & & 2 & 19 & 5 & 89 \\
\hline & M2 & 5 & 1 & & & & & 2 & & 8 & 9 & 2 & 1 & & & & 1 & 1 & 14 \\
\hline & $P 1$ & 2 & 2 & 3 & & & 1 & 1 & & 9 & 2 & 1 & 2 & & & 1 & 1 & & 7 \\
\hline & $\mathbf{P 2}$ & 2 & & & 1 & & & & & 3 & 1 & & & & & & 1 & & 2 \\
\hline & P3 & & & & & & & & & & & & & & & & & & \\
\hline & Saliva & 2 & 1 & & & & & & & 3 & 3 & & 2 & & & & 1 & 1 & 7 \\
\hline & No Sputum & $\overline{21}$ & 7 & 3 & & & 1 & 104 & 16 & 152 & 19 & 2 & 1 & & & & 106 & 20 & 148 \\
\hline & Not Returned & 3 & & 1 & & & & 6 & 6 & 16 & 5 & & 2 & & & & 6 & 6 & 19 \\
\hline & All & 95 & 22 & 15 & 1 & & 3 & 125 & 25 & 286 & 89 & 13 & 12 & 1 & & 3 & 135 & 33 & 286 \\
\hline
\end{tabular}

the results of the two questionnaires no distinction has been made between the different observers.

The design of the trial enables a comparison to be made of the inter- and intra-observer error associated with the questionnaires. On the evidence available there seems to be little to choose between them on this score. It is interesting that over a period of 6 months about 80 per cent. of the subjects gave consistent replies to individual questions about respiratory symptoms using either questionnaire. There was little difference in the overall prevalence of almost all individual respiratory symptoms at the two stages of the trial. Comparison of the measurements of $\mathrm{FEV}_{1 \mathrm{sec}}$ and FVC made for each subject on the two stages showed that there was no signi- ficant difference between the two sets of results. This confirms that the choice of the months of October and May for the two stages was successful in avoiding the possibility of complications due to "seasonal" differences (Morgan and others, 1964).

The trial included the collection of 1-hour sputum $\vec{\mathscr{}}$ specimens on successive days at each stage. There wæa g a considerable degree of variation between the volumes returned by certain subjects on successise days and at the two stages of the trial, although the average results were very similar. On the other hand the type of sputum produced showed little variation. In the further analysis of the results of the trial, the first specimen at each stage has been taken as the basic measure of sputum production.

[Appendices I and II are opposite and overleaf 


\section{APPENDIX I}

\section{MEDICAL RESEARCH COUNCIL}

\section{SHORTER RESPIRATORY SYMPTOMS QUESTIONNAIRE}

Modified Questions about Smoking Habits (as used by St. Thomas's Hospital Medical School)

\section{SMOKING HISTORY}

(28) Do you smoke?

If "YES": Do you inhale?

How much are you smoking now? cigarettes a day, with filters. cigarettes a day, without filters. oz. tobacco a week (hand-rolled). oz. tobacco a week (pipe).

How old were you when you started smoking regularly?

If not smoking now: Have you ever smoked?

If "NO" check:

Have you ever smoked as much as a cigarette a day for as long as a year?

If "YES":

How old were you when you started
smoking regularly?

Never Smoked

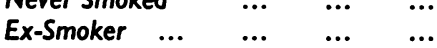

Present Smoker inhales $\quad \ldots . \quad \ldots$

Present Smoker doesn't inhale

Cigarettes filters ..

Cigarettes no filters $\quad \ldots \quad \ldots$

Handrolled $\ldots \quad \ldots, \quad \ldots, \quad \cdots$

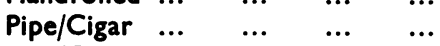

Pipe/Cigar + handrolled ... ...

Cigarettes + handrolled ...

Pipe/Cigar + cigarettes $\ldots . \quad \ldots$

Never smoked $\quad \ldots \quad \ldots \quad \ldots$

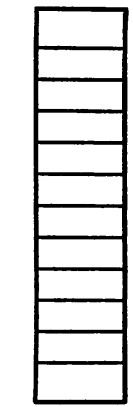

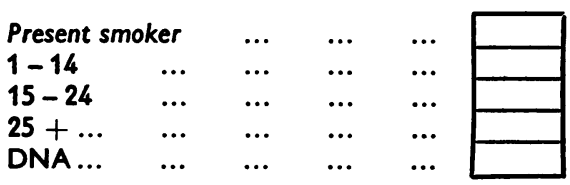

$\begin{array}{llllll}\text { Ex-smoker } & & & & & \\ 1-14 & \ldots & \ldots & \ldots & \ldots & \\ 15-24 & \ldots & \ldots & \ldots & \ldots & \\ 25+\ldots & \ldots & \ldots & \ldots & \ldots & \\ \text { DNA } \ldots & \ldots & \ldots & \ldots & \ldots & \end{array}$

How much were you smoking at that time?

Age started ...

Age stopped

Cigarettes a day, with filters.

Cigarettes a day, without filters.

oz. tobacco a week (hand-rolled).

oz. tobacco a week (pipe).

cigars.

(if non-smoker code $\mathrm{XX}$ )

Why did you give up smoking? Doctor

Unwell

Finance

Other

DNA 
PREAMBLE: "I am going to ask you some questions about your chest, about cough and spit for example. Please try and answer 'yes' or 'no'. Your answers will be treated confidentially."

\section{COUGH}

Do you cough when you get up or first thing in the morning?

(If "YES" to question 1, 80 to question 1A; otherwise go to question 2)

Do you cough like this on most days for as much as 3 months in the year?

Do you cough during the rest of the day? I don't mean just at the end of your shift (If "YES" to question 2, 80 to question 3; otherwise 80 to question 4)

Do you cough like this on most days for as much as 3 months in the year?...

\section{PHLEGM}

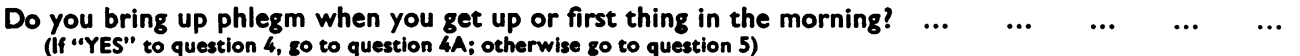

Do you bring up phlegm like this on most days for as much as 3 months in the year?

Do you bring up phlegm during the rest of the day? I don't mean just at the end of your shift ... (If "YES" to question 5, 80 to question 6; otherwise 80 to question 7)

Do you bring up phlegm like this on most days for as much as 3 months of the year?

\section{BREATHLESSNESS}

Do you have to walk slower than other people on level ground?

\section{WHEEZING}

Do you ever have wheezing or whistling in your chest? I don't mean when you have a cold

\section{WEATHER}

Does the weather affect your chest?

\section{SMOKING}

Do you smoke If "YES":

How much are you smoking? If "NO":

Have you smoked as much as one cigarette a day for one year? cigarettes ... $\quad \ldots \quad \ldots$ oz tobacco per week

$$
\text { ? }
$$

\begin{tabular}{llllll|l}
$\ldots$ & $\ldots$ & $\ldots$ & $\ldots$ & $\ldots$ & $\ldots$ & 10 \\
$\ldots$ & $\ldots$ & $\ldots$ & $\ldots$ & $\ldots$ & $\ldots$ & 11 \\
$\ldots$ & $\ldots$ & $\ldots$ & $\ldots$ & $\ldots$ & $\ldots$ & 12
\end{tabular}

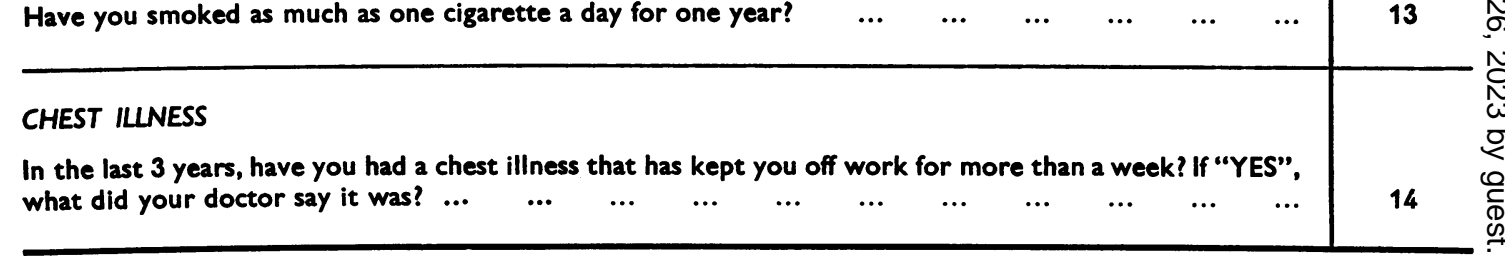

Assessment of Respiratory Symptoms Complex "YES" to 3 or 6 plus 7 or 8 or 9 or 14, or "YES" to 8 and 9. The replies to this questionnaire are recorded directly onto mark sense punch cards. 
PART II

\section{PREVALENCE OF SYMPTOMS AND RELATION TO VENTILATORY FUNCTION AND SPUTUM}

Because the first questionnaire to be asked of each subject tended to affect the answers given to the second questionnaire, the men examined have been divided into two groups for the assessment and comparison of the individual respiratory symptoms. Thus, the data relating to the MRC Questionnaire are based upon the replies given by the subjects to whom this questionnaire was applied first. Similarly, the data relating to the PFR Questionnaire are based on the replies given by the other half of the population. As the two groups were chosen at random and have much the same distribution of age, smoking habits, and ventilatory function, this sub-division provides a valid basis for comparison.

In order to make the best use of all the available data, the results given in this second part of this paper for the first stage of the trial refer to the whole group of 357 men examined on this occasion. This is in contrast to the treatment given in Part I which, in the interests of convenience of presentation, is based mainly on the $\mathbf{2 8 6}$ men who took part in both stages of the trial.

\section{Symptoms Relating to Cough and Sputum}

The MRC Questionnaire makes a distinction between summer and winter cough and sputum which does not appear in the PFR Questionnaire. In consequence, comparisons between the results obtained can be made only in terms of groups of symptoms which, although apparently equivalent, are based on questions with a different content and wording. The overall prevalences of the symptoms relating to cough and phlegm recorded using the two questionnaires are compared at Table $I^{*}$. For any particular symptom the results obtained at the first and second stages of the trial are, in general, in close agreement. The only significant difference is that between the figures for the men who reported one or more and two or more periods of increased cough and phlegm using the MRC Questionnaire at the first (autumn) and second (spring) stages of the trial. It appears that the results of this question may vary substantially according to the season of the year when the questionnaire is applied.

\footnotetext{
* See footnote on page 79 to Table II of Part I.
}

TABLE I

COMPARISON OF THE PREYALENCE OF CORRESPONDING COUGH AND PHLEGM SYMPTOMS REVEALED BY THE TWO QUESTIONNAIRES

\begin{tabular}{|c|c|c|c|c|}
\hline \multirow{2}{*}{ Group } & \multirow{2}{*}{ Symptoms } & \multirow{2}{*}{ Questions } & \multicolumn{2}{|c|}{$\begin{array}{l}\text { Prevalence } \\
\text { (Per cent.) }\end{array}$} \\
\hline & & & $\begin{array}{c}\text { First } \\
\text { Stage }\end{array}$ & $\begin{array}{l}\text { Second } \\
\text { Stage }\end{array}$ \\
\hline MRC First & $\begin{array}{l}\text { Morning Cough in } \\
\text { Winter } \ldots \\
\text { Morning Cough in } \\
\text { Summer . } \\
\text { Morning Cough in } \\
\text { Winter or Summer.. }\end{array}$ & $\begin{array}{c}1 \\
2 \\
1 \text { or } 2\end{array}$ & $\begin{array}{l}57 \\
40 \\
59\end{array}$ & $\begin{array}{l}65 \\
43 \\
65\end{array}$ \\
\hline PFR First & $\begin{array}{l}\text { Morning Cough } \\
\text { Persistent Morning } \\
\text { Cough } \ldots\end{array}$ & 1 & $\begin{array}{l}52 \\
41\end{array}$ & $\begin{array}{l}56 \\
42\end{array}$ \\
\hline MRC First & $\begin{array}{l}\text { Day or Night Cough } \\
\text { in Winter . . } \\
\text { Day or Night Cough } \\
\text { in Summer.. } \\
\text { Day or Night Cough } \\
\text { in Summer or Winter } \\
\text { Cough for More than } \\
3 \text { months of the Year } \\
\text { Cough, Grade } 2\end{array}$ & $\begin{array}{c}3 \\
4 \\
3 \text { or } 4 \\
5 \\
1,3,5\end{array}$ & $\begin{array}{l}56 \\
44 \\
58 \\
57 \\
41\end{array}$ & $\begin{array}{l}61 \\
43 \\
62 \\
55 \\
49\end{array}$ \\
\hline PFR First & $\begin{array}{l}\text { Cough All Day } \\
\text { Persistent All Day } \\
\text { Cough }\end{array}$ & $\begin{array}{l}2 \\
3\end{array}$ & $\begin{array}{l}42 \\
29\end{array}$ & $\begin{array}{l}38 \\
28\end{array}$ \\
\hline MRC First & 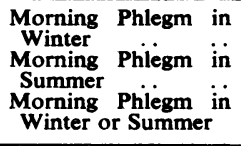 & $\begin{array}{c}6 \\
7 \\
6 \text { or } 7\end{array}$ & $\begin{array}{l}58 \\
45 \\
60\end{array}$ & $\begin{array}{l}57 \\
46 \\
57\end{array}$ \\
\hline PFR First & $\begin{array}{l}\text { Morning Phlegm } \\
\text { Persistent Morning } \\
\text { Phlegm } \quad \ldots\end{array}$ & $\begin{array}{l}4 \\
4 a\end{array}$ & $\begin{array}{l}56 \\
44\end{array}$ & $\begin{array}{l}49 \\
37\end{array}$ \\
\hline MRC First & $\begin{array}{l}\text { Day or Night Phlegm } \\
\text { in Winter } \\
\text { Day or Night Phlegm } \\
\text { in Summer. } \\
\text { Day or Night Phlegm } \\
\text { in Summer or Winter } \\
\text { Phlegm for More than } \\
3 \text { months of the Year } \\
\text { Phlegm, Grade } 2 \\
\text { One or more periods } \\
\text { of Increased Cough } \\
\text { and Phlegm } \\
\text { Two or more periods } \\
\text { of Increased Cough } \\
\text { and Phlegm }\end{array}$ & $\begin{array}{c}8 \\
9 \\
8 \text { or } 9 \\
10 \\
6,8,10 \\
12 \\
12\end{array}$ & $\begin{array}{l}58 \\
51 \\
59 \\
62 \\
39 \\
24 \\
13\end{array}$ & $\begin{array}{l}60 \\
46 \\
61 \\
59 \\
44 \\
17 \\
27\end{array}$ \\
\hline PFR First & $\begin{array}{l}\text { Phlegm All Day } \\
\text { Persistent Phlegm Ail } \\
\text { Day } \\
\end{array}$ & $\begin{array}{l}5 \\
6\end{array}$ & $\begin{array}{l}45 \\
33 \\
\end{array}$ & $\begin{array}{l}43 \\
30 \\
\end{array}$ \\
\hline $\begin{array}{l}\text { No. of } \\
\text { Subjects }\end{array}$ & $\begin{array}{l}\text { MRC First } \\
\text { PFR First }\end{array}$ & $\cdots$ & $\begin{array}{l}165 \\
192\end{array}$ & $\begin{array}{l}138 \\
148\end{array}$ \\
\hline
\end{tabular}


The prevalence of morning cough using the PFR Questionnaire is slightly, but not significantly, lower than that of morning cough in winter or summer (or morning cough in winter only) using the MRC Questionnaire, but the prevalence of persistent morning cough is in very good agreement with that of morning cough in summer using the MRC Questionnaire. When cough throughout the day is considered, the agreement between the two questionnaires is less close. The prevalence of all-day cough using the PFR Questionnaire is not significantly different from that of day or night cough in summer and cough (Grade 2) using the MRC Questionnaire. On the other hand, the prevalence of persistent all-day cough using the PFR Questionnaire is significantly lower than that of any of the equivalent symptoms using the MRC Questionnaire.

The phlegm symptoms follow a similar pattern to those relating to cough. There is reasonably good agreement between the prevalence of MRC morning phlegm in winter or summer and PFR morning phlegm, and also between MRC morning phlegm in summer and PFR persistent morning phlegm. On the other hand, the prevalence of MRC day or night phlegm is significantly higher than that of the corresponding symptoms using the PFR Questionnaire.

When the results were sub-divided in terms of age, similar trends were found in all age groups.

Fig. 1 (opposite) compares the prevalence of certain of the cough symptoms using the two questionnaires (as reported on the first stage of the trial) in the various age groups, and Fig. 2 (opposite) shows the corresponding results for the phlegm symptoms. The data for the second stage of the trial follow a similar pattern to those for the first stage.

Breathlessness, Wheeze, Weather affecting the Chest, and Chest Illness

As in the case of the questions about cough and sputum, the content and wording of the questions about breathlessness, wheeze, the effect of weather, and previous chest illness used in the two questionnaires are not exactly the same. Nevertheless, it is possible to select certain groups of symptoms which are apparently equivalent and a comparison of the results obtained using the two questionnaires is given in Table II. It will be noted that, with the exception of the questions about weather affecting the chest, similar results were reported at each stage of the trial for the two sets of questions. The answers given to questions about the effect of the weather would appear to be influenced by the climate during the period immediately before the inquiry is made.
COMPARISON OF THE PREVALENCE OF SYMPTOMS RELATING TO BREATHLESSNESS. WHEEZE, WEATHER, AND CHEST ILLNESS AS REVEALED BY THE TWO QUESTIONNAIRES

\begin{tabular}{|c|c|c|c|c|}
\hline \multirow{2}{*}{ Group } & \multirow{2}{*}{ Symptoms } & \multirow{2}{*}{ Questions } & \multicolumn{2}{|c|}{$\begin{array}{l}\text { Prevalence } \\
\text { (Per cent.) }\end{array}$} \\
\hline & & & $\begin{array}{l}\text { First } \\
\text { Stage }\end{array}$ & $\begin{array}{l}\text { Second } \\
\text { Stage }\end{array}$ \\
\hline MRC First & 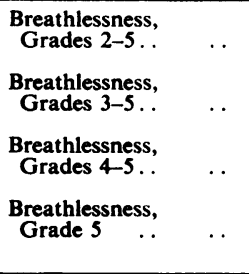 & $\begin{array}{l}(14,14 \\
(a-d)) \\
(14,14 \\
(a-d)) \\
(14,14 \\
(a-d)) \\
(14,14 \\
(a-d))\end{array}$ & $\begin{array}{l}33 \\
14 \\
10\end{array}$ & $\begin{array}{l}60 \\
41 \\
15 \\
10\end{array}$ \\
\hline PFR First & Breathlessness & 7 & 27 & 28 \\
\hline MRC First & $\begin{array}{l}\text { Wheeze } \\
\text { Wheeze with Colds .. } \\
\text { Wheeze apart from } \\
\text { Colds } \\
\text { Wheeze, Grade } 2 \quad \ldots\end{array}$ & $\begin{array}{l}15 \\
15,15 a \\
15,15 b \\
(15,15 \\
(a-c))\end{array}$ & $\begin{array}{l}58 \\
50 \\
36 \\
31\end{array}$ & $\begin{array}{l}59 \\
50 \\
38 \\
33\end{array}$ \\
\hline PFR First & $\begin{array}{crc}\text { Wheeze } & \text { apart } & \text { from } \\
\text { Colds } & \ldots & \ldots \\
\end{array}$ & 8 & 39 & 37 \\
\hline MRC First & $\begin{array}{l}\text { Weather affects Chest } \\
\text { Grades } 1 \text { and } 2 \\
\text { Weather affects Chest, } \\
\text { Grade } 2 \quad \ldots\end{array}$ & $\begin{array}{c}17 \\
17,17 f\end{array}$ & $\begin{array}{l}49 \\
35\end{array}$ & $\begin{array}{l}41 \\
29\end{array}$ \\
\hline PFR First & Weather affects Chest & 9 & 35 & 37 \\
\hline$\overline{\text { MRC First }}$ & $\begin{array}{l}\text { Chest Illness during } \\
\text { past } 3 \text { years } \\
\text { Chest Illness during } \\
\text { past } 3 \text { years, Grades } \\
1 \text { and } 2 \text {. } \\
\text { Chest Illness during } \\
\text { past } 3 \text { years, Grade } 2\end{array}$ & $\begin{array}{l}21 \\
21 \\
21\end{array}$ & $\begin{array}{r}26 \\
16 \\
5\end{array}$ & $\begin{array}{r}30 \\
17 \\
5\end{array}$ \\
\hline PFR First & $\begin{array}{c}\text { Chest Illness during } \\
\text { past } 3 \text { years }\end{array}$ & 14 & 21 & 22 \\
\hline $\begin{array}{l}\text { No. of } \\
\text { Subjects }\end{array}$ & $\begin{array}{ll}\text { MRC First } & \ldots \\
\text { PFR First } & \ldots\end{array}$ & $\begin{array}{l}\cdots \\
\ldots\end{array}$ & $\begin{array}{l}165 \\
192\end{array}$ & $\begin{array}{l}138 \\
148\end{array}$ \\
\hline
\end{tabular}

The prevalence of men with Grades 3 to 5 breathlessness using the MRC Questionnaire (which corresponds at least to shortness of breath walking at an ordinary pace on level ground) is significantly higher than that of men with breathlessness using the PFR Questionnaire (for which the qualifying symptoms are the same). In contrast, the reported prevalences of wheeze apart from colds using the two questionnaires are in good agreement. The wording of the questions leading to an assessment of weather affecting the chest, Grades 1 and 2, using the MRC Questionnaire is identical with that for weather affecting the chest using the PFR Questionnaire. However, the prevalence of the PFR symptom at the first stage of the trial was significantly lower than that of the corresponding MRC symptom, and in good agreement with the result for the MRC weather affecting the chest, Grade 2, which involves the 


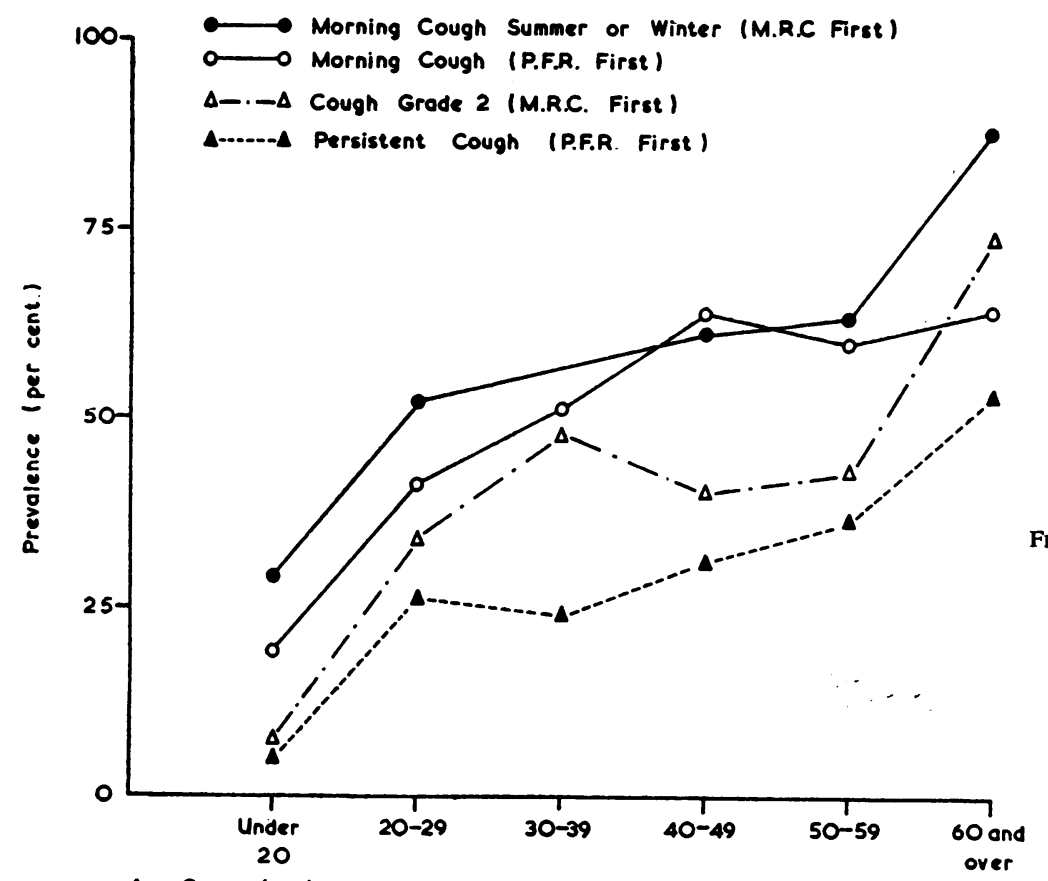

Fio. 1.-Prevalence of cough symptoms, by age group, using the two questionnaires.

Age Group (yrs)

Fig. 2.-Prevalence of phlegm symptoms, by age group, using the two questionnaires.

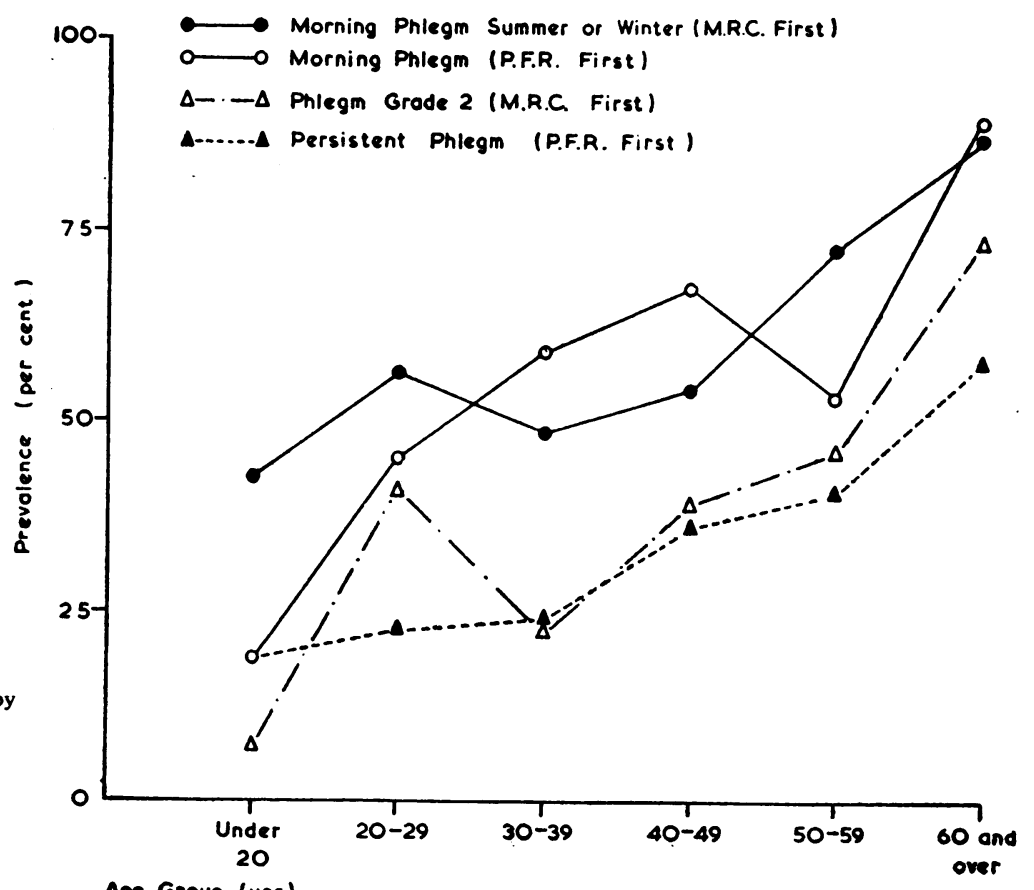

Age Group (yrs) 
further criterion that the effect of the weather leads to breathlessness. On the other hand, for the second stage of the trial, the prevalence of MRC weather affecting the chest, Grades 1 and 2, does not differ significantly from that of the corresponding PFR symptom. The MRC assessment of chest illness, Grades 1 and 2, is recorded for men who say that they have had at least one chest illness lasting for a week or more during the past 3 years. The PFR assessment of chest illness is based on exactly the same criteria, but the corresponding prevalence is consistently, but not significantly, higher.

\section{Respiratory Symptoms Complexes}

On the basis of the replies given to the individual questions using the MRC Questionnaire, an assessment may be made of the subject's symptoms complex in terms of "persistent cough and sputum", "chronic bronchitis", "simple chronic bronchitis", and the "chronic bronchitis syndrome" as defined previously. Similarly, the replies to the PFR Questionnaire may be assessed in terms of a "respiratory symptoms complex". The results obtained at the two stages of the trial are summarized at Table III, which shows a variation of between about 10 and 60 per cent. in the overall prevalence of the various symptom complexes. There was little difference between the results recorded at the two
TABLE III

COMPARISON OF THE ASSESSMENTS OF THE RESPIRATORY SYMPTOMS COMPLEX BASED ON THE ANSWERS GIVEN TO THE TWO QUESTIONNAIRES

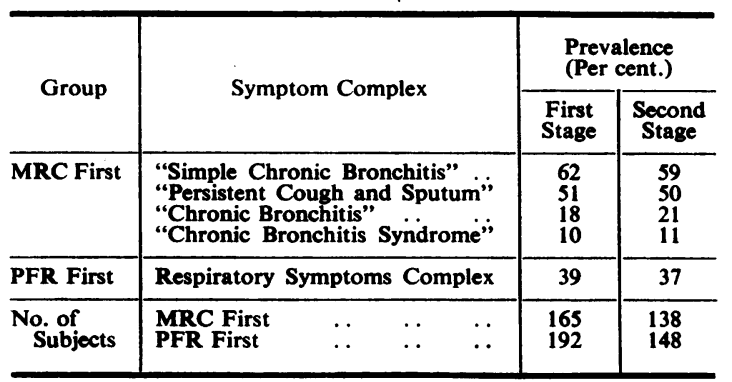

stages of the trial; the relation between prevalence and age at the first stage is shown at Fig. 3. The highest prevalence was that of MRC "simple chronic bronchitis", which increases fairly steadily from as much as 40 per cent. for the under 20 age group to about 80 per cent. for men aged 60 years and over. The next in order of prevalence is MRC "persistent cough and sputum", which varies from about 15 per cent. amongst the youngest men to about 75 per cent. amongst the oldest. This is followed by the PFR "respiratory symptoms complex", which shows the greatest and most consistent rate of increase of prevalence with age, varying from about

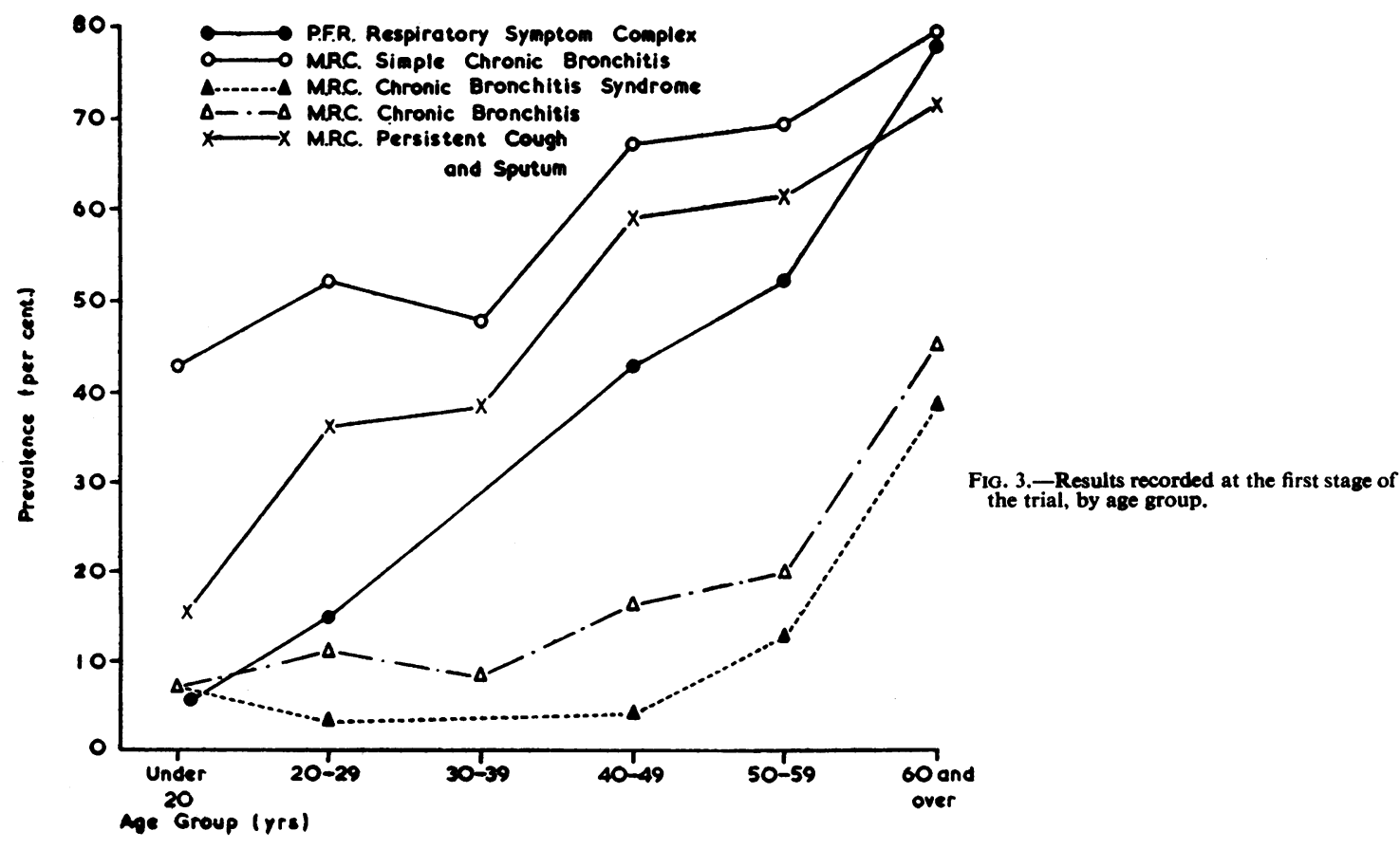


5 to about 80 per cent. over the range. The prevalence of MRC "chronic bronchitis" and "chronic bronchitis syndrome" shows a somewhat different pattern, with a comparatively slow rate of increase with age until the 50 to 59 -year age group is reached.

\section{Assessment of Smoking Habits}

The replies to the questions about smoking habits did not appear to be affected by the order in which the two questionnaires were applied, and a valid comparison can be made of the two sets of replies given by the whole group examined at each stage. Although the questions about smoking used in the two questionnaires are not exactly the same, each subject may be assessed in terms of smoker, non-smoker, and ex-smoker, using identical criteria. A comparison of the results obtained is given at Table IV, which demonstrates a high level of agreement. The current consumption of tobacco as assessed using the two questionnaires is shown at Table $\mathrm{V}$. Bearing in mind the different systems of coding, the corresponding results again show a high level of consistency.

\section{VENTILATORY FUNCTION}

Comparison of the ventilatory function measurements of the men with and without any particular group of respiratory symptoms provides a measure of the ability of those particular symptoms to dis- criminate between a "disabled" and a "nondisabled" group. Because ventilatory function tends to decrease with increasing age (Rogan, Ashford, Chapman, Duffield, Fay, and Rae, 1961) and the disability associated with any particular group of symptoms may also be dependent upon age, due account must be taken of the effect of age in any such comparison. By the same token, physique may also play a similar but probably considerably less significant role; because of the comparatively small numbers of men involved and the absence of significant differences in physique between the various groups which are to be compared, it was not considered worthwhile to make allowance for this factor also.

The average measurements of $F E V_{1 \mathrm{sec}}$ amongst the men assessed as being with and without the four types of respiratory symptom complex using the MRC Questionnaire and as being with and without the "respiratory symptoms complex" using the PFR Questionnaire at the two stages of the trial are given at Table VI (overleaf), which is sub-divided in terms of age.

The MRC and PFR data are again based upon different groups of men and for each group there is a similar tendency for $\mathrm{FEV}_{1 \mathrm{sec}}$ to decrease with increasing age. The results for the men with symptoms in the under 40-year and over 60-year age groups are somewhat unstable owing to the small

TABLE IV

COMPARISON OF SMOKING HABITS (IN TERMS OF SMOKER, NON-SMOKER, AND EX-SMOKER) REPORTED FOR THE SAME SUBJECTS USING THE TWO QUESTIONNAIRES

\begin{tabular}{|c|c|c|c|c|c|c|c|c|c|c|}
\hline \multirow{2}{*}{$\frac{\text { Stage }}{\underset{\text { Assessment }}{\text { MRC }}}$} & \multirow{2}{*}{\multicolumn{2}{|c|}{$\begin{array}{ll}\cdots & \cdots \\
\text { Classification }\end{array}$}} & \multicolumn{4}{|c|}{ First } & \multicolumn{4}{|c|}{ Second } \\
\hline & & & Smoker & Non-smoker & Ex-smoker & Total & Smoker & Non-smoker & Ex-smoker & Total \\
\hline \multirow{4}{*}{$\begin{array}{c}\text { PFR } \\
\text { Assessment }\end{array}$} & Smoker .. & . & 260 & 1 & 1 & 262 & 193 & 1 & - & 194 \\
\hline & Non-smoker & $\ldots$ & - & 61 & 3 & 64 & - & 50 & 2 & 52 \\
\hline & Ex-smoker & . & - & 1 & 30 & 31 & - & - & 40 & 40 \\
\hline & Total & .. & 260 & 63 & 34 & 357 & 193 & 51 & 42 & 286 \\
\hline
\end{tabular}

TABLE V

COMPARISON OF SMOKING HABITS (CURRENT CONSUMPTION OF TOBACCO (EQUIVALENT CIGARETTES PER DAY)) FOR THE SAME SUBJECTS USING THE TWO QUESTIONNAIRES

\begin{tabular}{|c|c|c|c|c|c|c|c|c|c|c|c|}
\hline \multirow{2}{*}{ 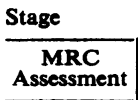 } & \multirow{2}{*}{$\begin{array}{l}\ldots \quad \ldots \\
\begin{array}{c}\text { Cigarettes } \\
\text { per day }\end{array}\end{array}$} & \multicolumn{5}{|c|}{ First } & \multicolumn{5}{|c|}{ Second } \\
\hline & & $1-14$ & $15-24$ & $\begin{array}{c}25 \\
\text { and Over }\end{array}$ & None & Total & $1-14$ & $15-24$ & $\begin{array}{c}25 \\
\text { and Over }\end{array}$ & None & Total \\
\hline \multirow{5}{*}{$\begin{array}{c}\text { PFR } \\
\text { Assessment }\end{array}$} & $1-10 \ldots$ & 79 & 3 & - & 2 & 84 & 63 & - & - & 1 & 64 \\
\hline & $11-20$. & 63 & 47 & 1 & - & 111 & 55 & 40 & 1 & - & 96 \\
\hline & Over 20 & 1 & 34 & 32 & - & 67 & 4 & 19 & 11 & - & 34 \\
\hline & None... & - & - & - & 95 & 95 & - & - & - & 92 & 92 \\
\hline & Total .. & 143 & 84 & 33 & 97 & 357 & 122 & 59 & 12 & 93 & 286 \\
\hline
\end{tabular}


AVERAGE FEV $_{1 \text { sec. }}$ (1) IN TERMS OF MRC AND PFR

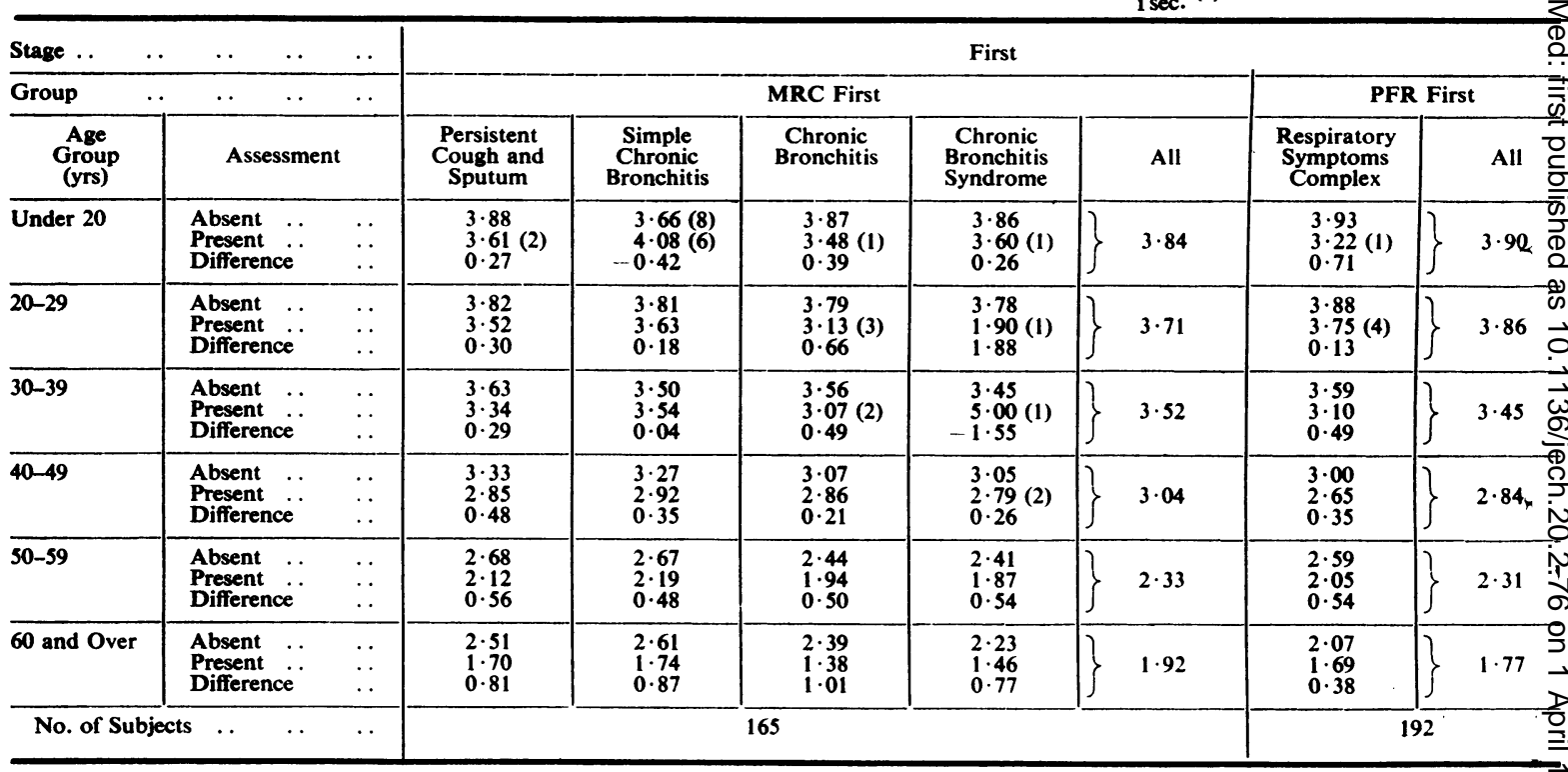

Where there were less than ten men in a particular group the exact number is given in brackets.

numbers involved. It is clear, however, that the PFR respiratory symptoms complex provides at least as good a measure of discrimination as any of the four criteria based on the MRC Questionnaire. Amongst the latter indices the average FEVs are highest for "persistent cough and sputum" and least for the "chronic bronchitis syndrome". This means, for example, that the men with the former have a higher ventilatory function on average than the men with the latter, which is consistent with the fact that there are about 60 per cent. of men with "persistent cough and sputum", in comparison with only about 10 per cent. with the "chronic bronchitis syndrome".

In order to study further the effect of the MRC Questionnaire on the replies given immediately afterwards to the PFR Questionnaire, the relation was examined between $F E V_{1}$ sec and age amongst the men with and without the PFR "respiratory symptoms complex" in the group to which the MRC Questionnaire was applied first. The differences in FEV $_{1 \text { sec }}$ between men of the same age associated with the respiratory symptoms complex were less marked and less consistent than amongst the group to whom the PFR Questionnaire was applied first. Thus it would seem that the application of the MRC Questionnaire reduced the discrimination of the replies to the PFR Questionnaire in terms of FEV $_{1 \text { sec. }}$ A similar study carried out in terms of the replies to the MRC Questionnaire lends further support to the conclusion that these results also were affected by the application of the other (PFR) Questionnaire immediately before.

The measurements of FVC followed a similar pattern to those of $F E V_{1 \mathrm{sec}}$.

\section{SPUTUm Volume AND TyPe}

The volume of sputum produced during the first hour after rising provides a further criterion for the assessment of the replies given on the previous day to the questions about the production of phlegm. Details of the average sputum volumes recorded at the two stages of the trial are given at Table VII (overleaf), where the results are sub-divided in terms of age group.

It will be noted that there is a general tendency for the average sputum volume to increase with increasing age, from about $0 \cdot 1-0 \cdot 2$ to about $4 \mathrm{ml}$. A similar pattern was followed at each of the two stages of the trial, although the volumes recorded for the $\mathbf{4 0}$ to 59-year age group at the second stage were somewhat lower and those for the over 60 -year age group were somewhat higher than the corresponding figures at the first stage.

In general, the average sputum volumes returned by the men without any particular symptom were considerably lower than the corresponding results for the men with that symptom. All the questions about phlegm using either questionnaire produced a 


\begin{tabular}{|c|c|c|c|c|c|c|}
\hline \multicolumn{7}{|c|}{ Second } \\
\hline \multicolumn{5}{|c|}{ MRC First } & \multicolumn{2}{|c|}{ PFR First } \\
\hline $\begin{array}{c}\text { Persistent } \\
\text { Cough and } \\
\text { Sputum }\end{array}$ & $\begin{array}{c}\text { Simple } \\
\text { Chronic } \\
\text { Bronchitis }\end{array}$ & $\begin{array}{l}\text { Chronic } \\
\text { Bronchitis }\end{array}$ & $\begin{array}{l}\text { Chronic } \\
\text { Bronchitis } \\
\text { Syndrome }\end{array}$ & All & $\begin{array}{c}\text { Respiratory } \\
\text { Symptoms } \\
\text { Complex }\end{array}$ & All \\
\hline $\begin{array}{r}3.62(5) \\
3.69(4) \\
-0.07 \\
\end{array}$ & $\begin{array}{r}3.62(5) \\
3.69(4) \\
-0.07 \\
\end{array}$ & $\begin{array}{c}3 \cdot 65(9) \\
=\end{array}$ & $\begin{array}{c}3 \cdot 65(9) \\
- \\
\end{array}$ & $3 \cdot 65(9)$ & 3.97 & 3.97 \\
\hline $\begin{array}{l}3.92 \\
3.65(8) \\
0.27\end{array}$ & $\begin{array}{l}3 \cdot 86 \\
3 \cdot 75(9) \\
0.11\end{array}$ & $\begin{array}{l}3.94 \\
3.31 \\
0.63\end{array}$ & $\begin{array}{l}3.93 \\
1.60(1) \\
2.33\end{array}$ & $3 \cdot 82$ & $\begin{array}{l}4 \cdot 16 \\
3.92(1) \\
0 \cdot 24\end{array}$ & $4 \cdot 15$ \\
\hline $\begin{array}{r}3.40(9) \\
3.75(6) \\
-0.35 \\
\end{array}$ & $\begin{array}{r}3.40(9) \\
3.75(6) \\
-0.35 \\
\end{array}$ & $\begin{array}{r}3.33 \\
3.96(5) \\
-0.63 \\
\end{array}$ & $\begin{array}{r}3.33 \\
4.90(2) \\
-1.57 \\
\end{array}$ & $3 \cdot 54$ & $\begin{array}{l}3 \cdot 60 \\
3 \cdot 17(5) \\
0 \cdot 43 \\
\end{array}$ & $3 \cdot 51$ \\
\hline $\begin{array}{l}3 \cdot 32 \\
2 \cdot 78 \\
0 \cdot 54\end{array}$ & $\begin{array}{l}3 \cdot 38 \\
2 \cdot 86 \\
0 \cdot 52\end{array}$ & $\begin{array}{l}3 \cdot 10 \\
2 \cdot 74 \\
0 \cdot 36\end{array}$ & $\begin{array}{l}3 \cdot 04 \\
2.69 \\
0.35\end{array}$ & $3 \cdot 01$ & $\begin{array}{l}3 \cdot 19 \\
2 \cdot 55 \\
0 \cdot 64\end{array}$ & $2 \cdot 86$ \\
\hline $\begin{array}{l}2.43 \\
2.13 \\
0.30\end{array}$ & $\begin{array}{l}2 \cdot 46 \\
2 \cdot 17 \\
0 \cdot 29\end{array}$ & $\begin{array}{l}2 \cdot 33 \\
2 \cdot 20(5) \\
0 \cdot 31\end{array}$ & $\begin{array}{l}2.36 \\
1.65(4) \\
0.71\end{array}$ & $2 \cdot 29$ & $\begin{array}{l}2 \cdot 57 \\
2 \cdot 01 \\
0 \cdot 56\end{array}$ & $2 \cdot 34$ \\
\hline $\begin{array}{l}2.22(2) \\
1.35(8) \\
0.87\end{array}$ & $\begin{array}{l}2.22 \text { (2) } \\
1.35(8) \\
0.87\end{array}$ & $\begin{array}{l}1.84(5) \\
1.21(5) \\
0.63\end{array}$ & $\begin{array}{l}1.84(5) \\
1.21(5) \\
0.63\end{array}$ & $1 \cdot 52$ & $\begin{array}{l}1.97(4) \\
1.58 \\
0.39\end{array}$ & $1 \cdot 67$ \\
\hline \multicolumn{5}{|c|}{138} & \multicolumn{2}{|c|}{148} \\
\hline
\end{tabular}

marked discrimination in terms of sputum production, and it is only amongst the older groups that an appreciable average volume of phlegm was obtained from men who did not also give a positive answer to the appropriate question. The questions which correspond most closely to the 1 hour sputum samples are those relating to morning phlegm and, not unexpectedly, these produced a rather better discrimination than the questions relating to sputum production throughout the day. In this respect there is little to choose between the two questionnaires. The best discrimination was, however, produced by the questions relating to persistent phlegm using the MRC Questionnaire.

The discrimination in terms of average sputum volume between the men giving positive and negative answers to the questions about phlegm using the MRC Questionnaire was slightly better amongst those to whom this questionnaire was applied first than amongst those to whom the PFR Questionnaire was applied first. A corresponding effect was noted for the replies given to the PFR questions about phlegm. These results provide further support for the conclusion that the questionnaire which was applied first affected the answers to the questionnaire which was applied second.

The results of the trial throw some light upon the relation between ventilatory function and sputum in this mining population. We have seen that $F E V_{1}$ sec and FVC tend to decrease with increasing age, whereas the average sputum production tends to increase. The average values of $F E_{1}$ sec recorded at the two stages of the trial, sub-divided in terms of age group and sputum volume, are shown in Table VIII (overleaf).

In general, the average $\mathrm{FEV}_{1 \mathrm{sec}}$ for a given age group tends to decrease with increasing sputum volume. In view of the close association between sputum volume and respiratory symptoms, this pattern is consistent with the reduction in ventilatory function associated with respiratory symptoms noted by Rogan and others (1961). The results for the men who failed to return their sputum containers are in close agreement with those for the men whose containers were returned empty, which suggests that the majority belong to the latter category.

It has already been noted that more than 80 per cent. of the sputum specimens were of type M1. Possibly because of the small numbers of subjects returning the other types of sputum, no significant association was observed between sputum type and age. Nor were there any significant variations in sputum type between the men giving positive or negative answers to the questions about phlegm using the two questionnaires. The average volumes of the type P1 and P2 specimens were slightly, but not significantly, higher than those of the type M1 and $\mathrm{M} 2$ specimens. 
94 W. W. HOLLAND, J. R. ASHFORD, J. R. COLLEY, D. C. MORGAN, AND N.J. PEARSON

TABLE VII

AVERAGE SPUTUM VOLUME (ml.) IN TERMS OF REPLIES TO THE QUESTIONS ABOUT PHLEGM IN PFR AND MRC QUESTIONNAIRES AND AGE GROUP

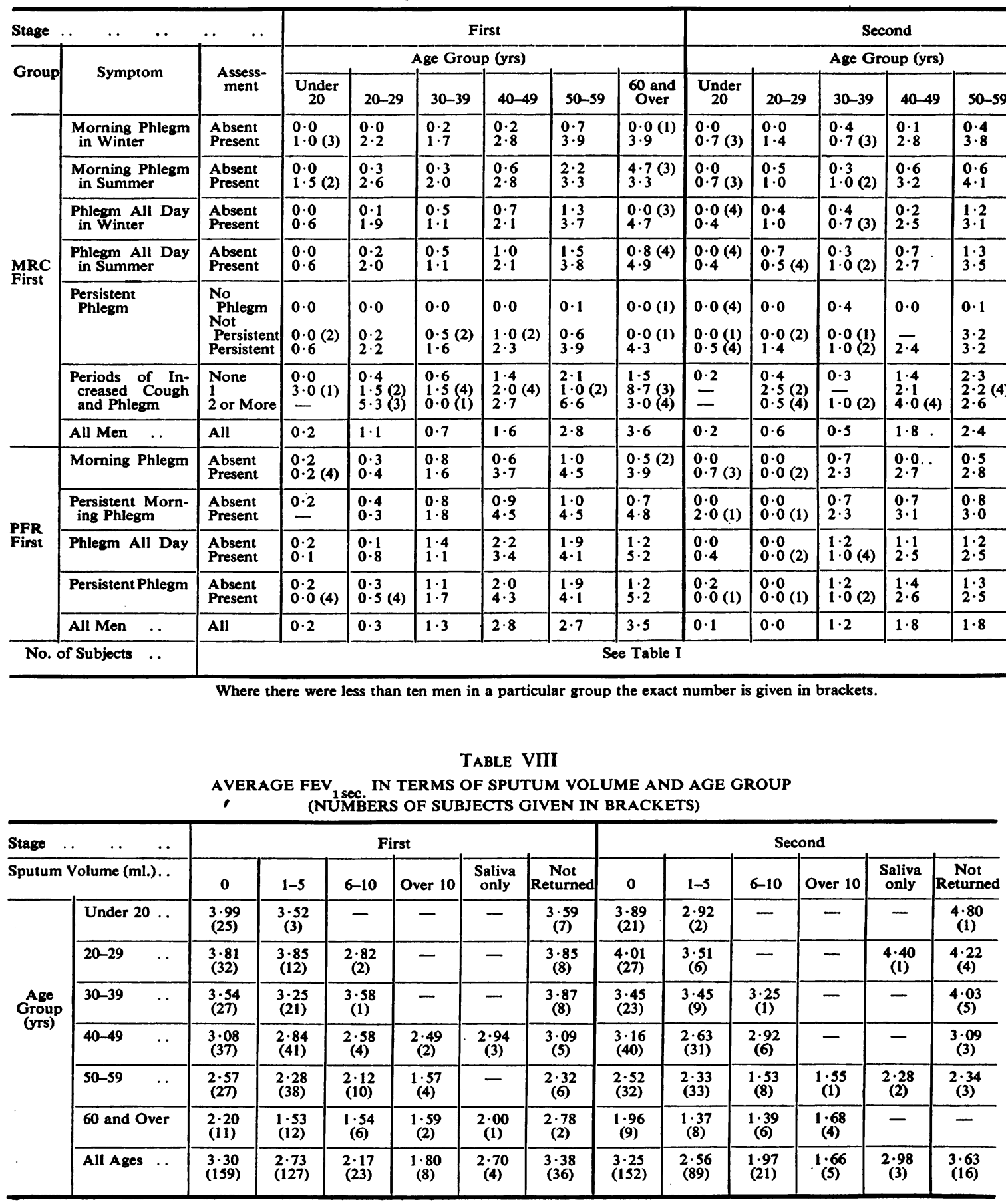




\section{COMMENT}

The main finding of the trial is the fact that the answers to questions about respiratory symptoms appear to depend upon the content and wording of the questions themselves and of any questions which have been asked previously. The plan of the trial involved the application of two respiratory symptoms questionnaires in succession to each subject and it is clear that the results of the questionnaire which was asked second were conditioned by the fact that the subject had already answered a similar questionnaire a few minutes earlier. Furthermore, the symptoms revealed by the questionnaire which was applied first were apparently also affected by the content of the earlier part of the same questionnaire. Synthesis of the replies given to one questionnaire to estimate particular sets of results corresponding to those obtained directly using the other questionnaire produced some marked inconsistencies. In particular, the distinction made in the MRC Questionnaire between winter and summer symptoms appears to have produced a different level of prevalence of cough and phlegm symptoms from that revealed by the PFR Questionnaire, which is not concerned with seasonal effects. On the other hand, the good agreement between the replies to the questions about smoking habits (which occur towards the end of both questionnaires) suggests that the less subjective items of information are little affected by factors of this kind. The respiratory symptoms questionnaire must therefore be regarded as a delicate instrument for collecting information about individual respiratory symptoms. The results obtained in terms of the prevalence of individual symptoms may be accepted as valid only in the context of the particular questionnaire which was used. Different questionnaires, with different wording and a different sequence of questions, may well lead to different estimates of the prevalence of particular symptoms. This emphasizes the need for precise standardization, in detail as well as in general terms, in comparative studies of respiratory symptoms.

The results obtained using a given questionnaire were, however, reasonably reproducible and were closely related to more objective measure of pulmonary function, such as FEV 1 sec, FVC and 1 hour sputum volume. Indeed, the replies given to the questions about morning phlegm were so well correlated with sputum volume that it would seem doubtful whether the effort required to collect such sputum specimens would be worthwhile in largescale survey work. The men examined are reasonably representative of British coalminers and the data collected during the trial provide a valid basis of comparison between the results of surveys based on the two questionnaires. In particular, the severity of symptoms characterized by the PFR "respiratory symptoms complex" represents a half-way stage between the MRC "persistent cough and sputum" and "simple chronic bronchitis" on the one hand, and "chronic bronchitis" and the "chronic bronchitis syndrome" on the other.

On the whole the results obtained at the two stages of the trial were in reasonably good agreement. The only questions for which significantly different results were obtained were those relating to periods of increased cough and phlegm and to the effect of weather on the chest using the MRC Questionnaire. On the assumption that there is unlikely to be any substantial change in chronic respiratory symptoms over a period as short as 6 months, it would appear that the answers to these particular questions may be conditioned to some extent by the season of the year and should therefore be regarded with some suspicion.

In an attempt to assess the precision of the two questionnaires as devices for discriminating between a "disabled" and a "non-disabled" group, the differences in the measurements of ventilatory function and sputum volumes between the men with and without particular symptoms were compared. It is interesting that there was little to choose between the two questionnaires and, in this respect, each may be regarded as equally valid. This particular analysis was carried out in relatively simple terms, on the basis of the differences between average results. A more complex multiple canonical analysis of the data is being undertaken and the results will be reported elsewhere.

In conclusion, therefore, this trial has shown that the PFR and MRC Questionnaires may lead to different estimates of the prevalence of certain individual respiratory symptoms in a population of working coalminers. Neither questionnaire has any clear advantage over the other in terms of inter- or intra-observer error. Nor is there any difference in the discrimination of the answers given to either questionnaire in terms of ventilatory function or sputum production.

\section{Summary}

An investigation is described to compare in the same population of coalminers the results of applying both the "Short Questionnaire on Respiratory Symptoms" of the Medical Research Council, and a similar but even more concise questionnaire used in the Pneumoconiosis Field Research Scheme of the National Coal Board. 
The inter- and intra-observer error associated with the application of the questionnaires and the consistency of replies to them are demonstrated. The relationship between these replies and some objective measurements of pulmonary function is also shown.

It is concluded that the results obtained by using either questionnaire are reasonably reproducible, and they are equally discriminatory when tested against the measures $\mathrm{FEV}_{1 \mathrm{sec}}, \mathrm{FVC}$, and 1 hour sputum volumes; however, the use of these two questionnaires may lead to different estimates of the prevalence of certain individual respiratory symptoms or of combinations of symptoms.

It is also shown that the answers to any question not only depend on the content and wording of that particular question, but may also be affected by the content and wording of questions (or sets of questions) previously asked. This finding emphasizes the need for precise standardization, in detail as well as in general terms, in comparative studies of respiratory symptoms.

The authors are grateful to Dr J. M. Rogan for his advice and encouragement at all stages of the work. They also wish to thank the staff of the Pneumoconiosis Field Research, who assisted with the collection and analysis of the data.

\section{REFERENCES}

Ashcroft, T. (1965). Brit. med. J., 1, 288.

Ashford, J. R., Forwell, G. D., and Routledge, R. (1960). Brit. J. industr. Med., 17, 114. (1960). "The Pattern of Respiratory Symptoms". (Unpublished National Coal Board Report).
Cochrane, A. L., Chapman, P. J., and Oldham, P. D. (1951). Lancet, 1, 1007.

College of General Practitioners. (1961). Brit. med. J., 2, 973.

Elmes, P. C., Dutton, A. A. C., and Fletcher, C. M. (1959). Lancet, 1, 1241.

Fairbairn, A. S., Wood, C. H., and Fletcher, C. M. (1959). Brit. J. prev. soc. Med., 13, 175.

Fay, J. W. J. (1957). Nature (Lond.), 180, 309. and Rae, S. (1959). Ann. occup. Hyg., 1, 149.

Fletcher, C. M., Elmes, P. C., Fairbairn, A. S., and Wood, C. H. (1959). Brit. med. J., 2, 257. and Tinker, C. M. (1961). Ibid., 1, 1491.

Higgins, I. T. T. (1957). Ibid., 2, 1198. (1961). "The Role of Irritation in Chronic Bronchitis", in "Bronchitis: An International Symposium, University of Groningen, April, 1960', ed. N. G. M. Orie and H. J. Sluiter, pp. 31-42. Royal Van Gorcum, Assen, Netherlands. Cochrane, A. L., Gilson, J. C., and Wood, C. H. (1959). Brit. J. industr. Med., 16, 255.

Holland, W. W. (1963). Arch. environm. Hlth., 6, 9.

M.R.C. Committee on the Aetiology of Chronic Bronchitis. (1960). Brit. med. J., 2, 1665.

(1961). "Instructions for the Use of the Short Questionnaire on Respiratory Symptoms, 1960"'.

Miller, D. L. (1963). Amer. Rev. Resp. Dis., 88, 473.

-, Tinker, C. M., and Fletcher, C. M. (1965). Brit. med. J., 1, 291.

Morgan, D. C., Pasqual, R. S. M., and Ashford, J. R. (1964). Brit. J. prev. soc. Med., 18, 88.

Olsen, H. C., and Gilson, J. C. (1960). Brit. med. J., $1,450$.

Payne, S. L. (1951). "The Art of Asking Questions." (Studies in Public Opinion, No. 3). Princeton University Press, Princeton, New Jersey.

Rogan, J. M., Ashford, J. R., Chapman, P. J., Duffield, D. P., Fay, J. W. J., and Rae, S. (1961). Brit. med. J., $1,1337$. 